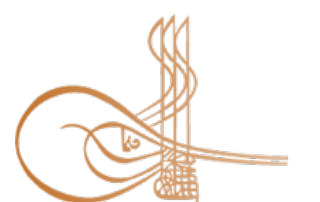

www.turkishstudies.net/social
Turkish Studies - Social Sciences

eISSN: $2667-5617$

Research Article / Araștırma Makalesi

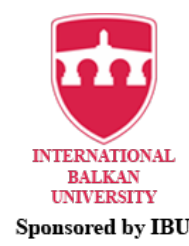

Sponsored by IBU

\title{
Logolarda Kullanılan Figürlerin Coğrafi Analizi: Giresun İli, İlçe Belediyeleri Örneği
}

\author{
Geographical Analysis of the Figures Use Logos: The Case of District Municipality of Giresun \\ Province
}

Eren Şenol ${ }^{*}$

\begin{abstract}
In today's world, symbols called emblems and logos are used to give identity to legal entities / institutions, to promote them and to make them a brand. The symbols called logo are used by the municipalities for the same reasons. The Municipality logos used represent the space in addition to the institution. The Municipality Logos reflect the image of people (designers and city dwellers) about the place. The Municipality Logos contain natural and human environmental elements in the region. For these reasons, logos have become one of the subjects worth examining geographically. In this study, logos of district municipalities of Giresun province were analyzed with a geographical approach by focusing on spatial features and used figures. In this context, the designers of the logos were interviewed for data supply. From them, information was obtained about the figures used and the reasons for their preference. The compiled data are grouped by theme analysis method. As a result, it was determined that 24 different figures were used 74 times in total in 16 logos. Giresun has a coast and lush plant cover. Hazelnuts and fish are significant in its culture and economy. These things are depicted on the logos. Figures of hazelnuts, sea, creek, mountains, trees and castles are used in many of the designs. It was determined that natural environment elements were used more in the logos. In terms of the figures and number of figures used, it has been determined that there are differences between the coast districts and the inner districts. Some logos are insufficient to represent the institution and service area. Theirs have been suggested that it does not contribute sufficiently to the branding process. Suggestions are presented.
\end{abstract}

Structured Abstract: Today, symbols called emblems or logos are used to gain identity, introduce and brand legal entities and institutions. Municipalities are one of the institutions using logos and emblems. There are 1,389 municipalities in Turkey's current local management system. Of them, 386 are towns, 403 are districts, 519 are sub-provincial metropolises, 51 are provincial centers, and 30 are metropolises (URL 1). Most of them have emblems or logos.

Logos that are the products of graphic design and have an artistic value are expected to have an aesthetic appearance, be printed for little cost, be used on many different surfaces and be available in a variety

\footnotetext{
* Doktor Öğretim Üyesi, Giresun Üniversitesi, Fen - Edebiyat Fakültesi, Coğrafya Bölümü Asst. Prof. Dr., Giresun University, Faculty of Arts and Sciences, Department of Geography. ORCID 0000-0003-2510-8491 eren.senol@giresun.edu.tr

Cite as/ Atıf: Şenol, E. (2020). Logolarda kullanılan figürlerin coğrafi analizi: Giresun ili, ilçe belediyeleri örneği.

Turkish Studies - Social, 15(4), 2141-2169. https://dx.doi.org/10.29228/TurkishStudies.42771

Received/Geliș: 05 April/Nisan 2020

Accepted/Kabul: 20 June/Haziran 2020

Copyright $($ INTAC LTD, Turkey
} 
of dimensions and be applicable on various surfaces (Çakmak, 2013: 1321; Köroğlu ve Yağc1; 2018: 65; Demirkol, 2019: 15-19). Academics in different fields examine and analyze the suitability of logos' features and their contribution to the marketing of space and creating city brands (Özer 2003, Büyükçanga 2003, Çamdereli 2006, Jansson ve Power 2006, Byrom ve Lehman 2007, Giritlioğlu ve Avcıkurt 2010, Zeren 2011, Vermeer 2011, Demir 2013, Hildreth 2013, Govers 2013, Kavaratzis ve Hatch 2013, Y1lmaz 2015, Kavuran ve Çetinkaya 2016, Yenipınar ve Yıldırım 2016, Zeybek ve Ünlü 2016, Adamus Matuszynska ve Dzik 2017, Çeliker ve Tokoğlu 2017, Fettahlıoğlu, Yıldız ve Göksu 2017, Kurtoğlu 2017, Nas ve Topaklı 2017, Tarlakazan ve Tıngır 2018, Özsöz 2018, Köroğlu ve Yağcı 2018, Bilirdönmez ve Şahin 2019, Görgülü 2019, Papp-Vary ve Farkas 2019).

Geography is a science that investigates human interaction with space. Municipal logos are worth examining geographically because they represent spaces, contribute to the marketing of space, include natural and human environmental elements and depict images of the people who prepare and use municipal spaces. Logo analysis based on the principles of geography was conducted by Aliağaoğlu (2007) for the first time in the Turkish literature. Others have followed this analysis (Şenol ve Saraçoğlu 2013, Uzun ve Özcan 2014, Yıldırım 2018, Türkan 2018, Aliağaoğlu ve Uğur 2018). This study analyzes the municipal logos of Giresun Province based on the principles of geography. It aimed to determine the environmental factors that affect the diversity of their elements, their contribution to the marketing of space and propose new figures for use. The data were collected in interviews with designers and by examining documents. The compiled data are grouped by theme analysis method.

Designs that depict the natural and human environment features of the region compared to the typographic regulations are selected more in the municipal logos of Giresun. In the province's 16 municipal logos, 26 different figures are used 74 times. These logos include an average of 4.6 elements. This rate is relatively higher than those of the previous studies. There is more figure diversity in the municipal logos of Dereli, Giresun, Piraziz, Keşap and Güce, and fewer in the municipal logos of Espiye, Doğankent, Şebinkarahisar, Alucra, Çamoluk and Çanakçı. These data indicate that the coastal municipalities use more figures than those in the interior.

The municipal logos include combinations of figures symbolizing both the natural and human features of the province. They include 10 depictions of the natural environment that are used 41 times, and 16 elements that depict the human environment that are used 33 times. The elements of the human environment are more diverse, even though they are used less. This is because neighboring municipalities with similar natural environments have to use different elements of the human environment to differentiate themselves.

Of the 10 figures of the natural environment, most (8) are used by the coastal districts. The districts in the interior use only 4 of these 10 figures. As a result, elements of the natural environment are used in the coastal side more than the districts in the interior.

The elements in the logos indicate certain differences between the coast, the middle and the southern part of the province. Figures of sea, hazelnuts, castles, fish, and seagull figures are used by the coastal districts. Figures of hazelnuts, running water and trees are prominent in the logos of the districts in the middle of Giresun. The logos of the districts of its southern part do not include depictions of plants and tend to emphasize beekeeping.

Giresun has a coast and lush plant cover. Hazelnuts and fish are significant in its culture and economy. These things are depicted by the logos. Figures of hazelnuts, sea, running water, mountains, trees and castles are used in many of the designs.

Hazelnuts are drawn big and in the middle of many of the logos of the districts. Products such as corn and black cabbage are also significant in its culture, but they have less economic value and are not included in the municipal logos. Economic values have overpassed cultural values.

Since Giresun does not include many structures and artifacts related to the Turkish-Islamic civilization, Giresun's logos do not include bridges, tombs or any historical structures other than castles.

Colors have psychological effects, and the choices of colors in the logos pay attention to them (Okay, 2000: 144-146; Işıkl1, 2012: 57-77; Ceylan, 2015: 315-320 Gross, 2019: 212). Green is used for plants, blue for running water and yellow for honey in the municipal logos of Giresun. The color preferences in the province's municipal logos represent its natural and human features rather than subliminal messages. They are 
also intended to be aesthetically pleasing. Sometimes, figures in logos have mythological meanings, but Giresun's municipal logos do not.

Giresun's municipal logos include geographical formations, plants, hydrographic features, establishment dates and agricultural products. The natural beauties and endemic breeds that make Giresun different from other provinces are not used in its municipal logos. Nor are historically important people (e.g., Topal Osman), cultural elements (e.g., kemancha, serender, transhumance culture), endemic products (Tamzara weaving, the Giresun frying pan), industries (hazelnuts, tea factories) or animal breeding included in the logos. Hazelnuts (as a registered geographical product) and the Piraziz apple are used in logos, but Görele ice cream, Tamzara weaving, sugar bean are not used because they are no longer registered. Corn and black cabbage have also been ignored even though they have a significant place in Giresun's culture. These products can be used in logos.

Giresun's municipal logos represent the district in general rather than the municipality. They also have an informative side and introduce the city. However, they do not accomplish either marketing or branding. Efforts are being made to increase tourism in the province, so figures that serve its tourism industry should be created, and research on brands, mascots and slogans should be done.

Keywords: Geography, Logo, City, City Image, Giresun

Öz:

Günümüz dünyasında tüzel kişi ve kurumlara kimlik vermek, onları tanıtmak, marka yapmak için amblem ve logo adı verilen semboller tasarlanmakta, kullanılmaktadır. Bunları kullanan kurumlardan biri de belediyelerdir. Belediye logoları, kuruma ek olarak hizmet bölgesini temsil eder; tasarımcıların ve şehir sakinlerinin yer hakkındaki imajlarını yansıtırlar. Mekânın doğal ve beşeri çevreye ilişkin unsurlarını içerirler. $\mathrm{Bu}$ çalışmada Giresun ilinin ilçe belediyelerinin logoları, mekânsal özelliklere ve kullanılan figürlere odaklanılarak, coğrafi yaklaşımla analiz edilmiştir. Veri temini için logoların tasarımcılarıyla görüşülmüş; onlardan kullanılan unsurlar ve bu unsurları tercih nedenleri hakkında bilgi edinilmiştir. Derlenen veriler tema analizi yöntemi ile gruplandırılmıştır. Sonuç olarak 16 logoda, 26 farklı konuda, toplam 74 figürün kullanıldığ1 görülmüştür. Giresun denize kıyısı bulunan, gür bitki örtüsüne sahip olan, kültürel yapısında ve ekonomisinde fındık ve balığın önemli yer tuttuğu bir ildir. İlin bu genel yapısı logolarda karşılığını bulmuştur. Tasarımlarda fındık, deniz, akarsu, dağ, ağaç ve kale figürlerinin daha çok tercih edildiği; doğal çevre özelliklerine oranla beşeri çevre özelliklerine daha fazla yer verildiği tespit edilmiştir. Kullanılan unsur çeşidi ve sayısı bakımından kıyı kuşağındaki ilçe belediyeleri ile iç kesimde yer alan belediyelerin logoları arasında kayda değer farklılıklar olduğu belirlenmiştir. Bazı logoların kurumu ve hizmet bölgesini temsil etmek için yetersiz kaldığı; marka oluşturma sürecine yeterince katkıda bulunmadığg ileri sürülmüştür. Öneriler sunulmuştur.

Anahtar Kelimeler: Coğrafya, Logo, Şehir, Şehir İmajı, Giresun.

\section{Giriş}

İnsanlar duygu ve düşüncelerini beden dili, söz, müzik, resim ve yazı ile ifade yoluna giderler. Bazı durumlarda işaret, simge ve semboller kullanarak öz bir şekilde daha fazlasını, daha geniş bir kitleye aktarma yolunu seçerler. Bu işaret, simge ve sembolleri belirlerken, tarih boyunca genellikle yakın çevrede bulunan doğal ve beşeri unsurlardan beslendikleri gözlenmektedir. Bayraklarında (Saraçoğlu ve Kaya, 2010; Yiğit, Çakır, Yıldız ve Aslım, 2011; Saraçoğlu, 2012), paralarında (Kızılçaoğlu, 2014), kurum amblemlerinde (Keskin Karaalan, 1998; Yerkan, 2010; Özsoy, Tuncay ve Uğur, 2017; Aka, Gülbahçe ve Saki, 2018; Demirkol, 2019) bu unsurlara yer verdikleri görülmektedir.

Günümüz dünyasında tüzel kişiliklere ve kurumlara kimlik kazandırmak, bunları tanıtmak, marka haline getirmek amacı ile amblem ve logo adı verilen semboller kullanılmaktadır. Amblem, eski Yunanca'da simge olarak adlandırılmıştır. Günümüzde ise bir nesneyi ya da bir kurumu temsil eden harf veya çeşitli işaretlerin görüntüsü olarak tanımlanmaktadır (Arıel Mazlum, 2009: 20). 
Becer'e (1997: 194) göre amblem "ürün ya da hizmet üreten kuruluşlara kimlik kazandıran, sözcük özelliği göstermeyen, soyut ya da nesnel görüntülerle veya harflerle oluşturulan simgedir”. Tepecik'e (2002: 62) göre amblemler okuma yazması olmayan insanlar dâhil toplumun her tabakasına seslenebilmektedir. Çoğu zaman amblem ile aynı anlamda kullanılan logolar aslında amblemden farklıdır. Çünkü logolar iki ya da daha fazla tipografik karakterin sözcük halinde okunacak biçimde bir araya getirilmesi ile oluşurlar (Becer, 1997: 195). Başka bir anlatımla amblemler çizgi ve resimle yapılan işaretler iken logolar çizgi, resim ve yazı ile ya da sadece yazıyla yapılan işaretlerdir (Gemci, Gülşen ve Babasakal, 2009: 110). Bu yönleri ile logolar okuryazar kesime de hitap ederler. Mal ve hizmetlerin halkın tümü üzerinde daha kalıcı bir etki bırakması amacıyla amblemlerle birlikte de kullanılırlar.

Son yıllarda küreselleşmenin artması ülkeler ve hatta şehirler arasında bir rekabet ortamı oluşturmuştur (Çamdereli, Varlı, Varlı ve Gürer, 2006: 236; Kaypak, 2013: 343; Kızıltaş, 2017: 214). Bu süreçte şehre girişimcilerin, nitelikli nüfusun, turistlerin, öğrencilerin, organizatörlerin vb. ilgisini çekmek (Kotler vd., 1993: 24'ten aktaran Vural, 2010: 60; Hospers, 2010: 2077); mevcut nüfus ile firmaların yerinde kalmasını sağlamak için (Jansson ve Power, 2006: 10) mekanın pazarlanması ve şehrin markalaşması (Kavaratzis, 2007: 696; Braun, 2008: 35) yaklaşımları önem kazanmıştır. Amblem ve logolar da mekânı pazarlamak ve şehir markası oluşturmak için araç olarak kullanılan unsurlardan biri haline gelmiştir (Jansson ve Power, 2006: 16; Giritlioğlu ve Avcıkurt, 2010: 80-84; Zeren, 2011: 192; Vermeer, 2011: 75; Kavaratzis ve Hatch, 2013: 74; Yenipınar ve Yıldırım, 2016: 31; Çeliker ve Tokoğlu, 2017: 146-147; Fettahlıŏlu, Yıldız ve Göksu, 2017: 1933-1934; Kurtoğlu, 2017: 11-13; Özsöz, 2018: 24; Görgülü, 2019: 74-80). Hatta en yaygın olarak kullanılan yöntem slogan ve logo birleşimidir (Jansson ve Power, 2006: 32). Mekân pazarlama sürecinde logolar, bazılarına göre çok önemli iken (Hildreth, 2013: 217); kimilerine göre ise hafif bir etkisi olduğu için gereksiz bir arayıştır (Govers, 2013: 74).

Türkiye'de, mevcut yerel yönetim sistemine göre 386'sı belde, 403'ü ilçe, 519'u büyükşehir ilçe, 51'i il ve 30'u da büyükşehir statüsünde olmak üzere toplam 1389 belediye bulunmaktadır (URL 1). Büyük çoğunluğunun amblem ve logosu vardır. Bunlarda tipografik düzenlemelerden ziyade daha çok yakın çevreye özgü doğal ve beşeri unsurların tercih edildiği görülmektedir (Aliağaoğlu, 2007: 281-282; Çakmak, 2013: 1318; Köroğlu ve Yağc1, 2018: 72 -74; Bilirdönmez ve Şahin, 2019: 46).

Yerleşmelerin imajı son dönemlerde popüler araştırma konularından biridir. Özellikle şehir yerleşmelerinin imajı konusunda yazılan eserlerde artış söz konusudur. Bu çalışmaların bazıları, anket ve görüşme yöntemleri ile toplanan verilerin analizine dayanmaktadır (Lynch, 1960; Jansson ve Power, 2006; Özdemir ve Karaca, 2009; Geçikli, 2013; Karadağ ve Turut, 2013; Demirel, 2014; Sağdıç, 2014). Logosu bulunan ilçe belediyelerinin çoğu, hatta yönetim kriterini esas alan Türkiye İstatistik Kurumu'na (TÜIK) göre hepsi, şehir statüsündeki yerleşmelerdir. Logolar, ilgili şehrin, bunları tasarlayanlardaki imajlarını yansıtmaktadır. Bunların kullanılabilmesi için 5393 sayılı Belediye Kanunu'nun 81. Maddesi uyarınca belediye meclisi kararı gereklidir (Resmi Gazete, 2005). Dolayısı ile logoların hem tasarlayanların, hem kabul edenlerin hem de kullanım sonrası eleştiri dozunun düşük olması dikkate alınırsa yöre sakinlerinin ilgili şehre ilişkin genel imajlarını yansıttığı söylenebilir.

Grafik ve tasarım ürünü olup sanatsal açıdan da değer taşıyan logolarda, estetik görünüm, baskı maliyetinin düşük olması, farklı boyutlarda kullanılabilirlik, çeşitli yüzeylere uygulanabilirlik gibi özellikler aranır (Çakmak, 2013: 1321; Köroğlu ve Yağc1; 2018: 65; Demirkol, 2019: 15-19) . $\mathrm{Bu}$ yönleri ile farklı bilim dalına mensup araştırmacılar tarafından da inceleme konusu olarak tercih edilirler. Coğrafya, insan mekân etkileşiminin araştırıldığı bilim dalıdır. Belediye logoları kuruma ek olarak mekânı temsil ettiği, mekânın pazarlanmasına katkı sunduğu, yöreye özgü doğal ve beşeri 
çevre unsurlarını içerdiği, hazırlayanların ve kullananların ilgili mekâna ilişkin imajlarını yansıttı̆̆ı için coğrafi açıdan incelemeye değer konulardan biri haline gelmiştir.

Papp-Vary ve Farkas (2019: 49) tarafından Birleşmiş Milletler'in tanıdığı 193 ülkenin turizm logoları analiz edilmiştir. Sonuçta logolarda ulusal bayrak renklerinin (68 ülke), bitki - hayvan (38 ülke), güneş (31 ülke) ve su (28 ülke) figürlerinin yaygın bir şekilde kullanıldığı; 22 ülkenin ise logosunun olmadığı belirlenmiştir. Zeybek ve Ünlü (2016: 36) tarafından Avrupa Birliği’ne üye ülkelerin turizm logo ve sloganları irdelenmiş; coğrafi ve kültürel karakterlerin; tarihi, arkeolojik ve teknolojik karakterlere göre daha fazla kullanıldığı tespit edilmiştir. Byrom ve Lehman (2007: 8) tarafindan Tasmanya logoları incelenmiş; su ve yerşekillerine ait unsurlara daha çok yer verildiği kaydedilmiștir. Adamus Matuszynska ve Dzik (2017: 108) tarafindan Silezya (Polonya) Bölgesi’ndeki yerleşmelerin logolarına odaklanılmış; küçük yerleşmelerin logolarında tipografik düzenlemelere oranla coğrafi görünümü yansıtan figürlere daha çok yer verildiği tespit edilmiştir.

Ülkemiz il ve ilçe belediyelerinin logo ve amblemleri üzerine üretilmiş çok sayıda çalışma bulunmaktadır (Özer 2003; Büyükçanga 2003, 2004; Çamdereli 2006; Demir, 2013; Yılmaz 2015; Kavuran ve Çetinkaya 2016; Nas ve Topakl1, 2017; Tarlakazan ve Tingır, 2018; Köroğlu ve Yağc1 2018). Coğrafyacılar tarafından kayda değer ilk eser ise Aliağaoğlu tarafından kaleme alınmıştır. "Lakap ve Logolarda Türkiye Şehirleri: Anlamların Coğrafyası" başlıklı bu öncü çalışmada il belediyesi logolarında 60'tan fazla sembol kullanıldığı, en çok tarımsal ürünlerin, kalelerin, camilerin ve harflerin tercih edildiği belirtilmiştir (Aliağaoğlu, 2007: 74). Şenol ve Saraçoğlu (2013: 339-341) tarafindan Sinop ili valilik ve ilçe belediyelerinin amblemleri irdelenmiştir. Bu amblemlerde çoğunluğu doğal çevre özelliklerini yansıtan 22 farklı unsura yer verildiği; kıyıda yer alan ilçe belediyelerinin amblemlerinde daha fazla figür kullanıldığı; iç kesimlerde yer alan ilçelerde beşeri, kıyıda yer alan ilçelerde ise doğal çevre özelliklerine ilişkin unsurların daha çok tercih edildiği tespit edilmiştir. Ayrıca amblemlerde belediye sınırları dışındaki unsurların kullanıldığı, bu yönleri ile amblemlerin belediye hizmet alanından ziyade ilçe genelini temsil ettiği ileri sürülmüsstür. Uzun ve Özcan (2014: 286-288) tarafindan Kocaeli ili belediye logolarındaki coğrafi semboller analiz edilmiş; 13 belediye logosunda 18'i doğal çevre özelliklerini, 23'ü beşeri çevre özelliklerini yansıtan toplam 41 unsurun kullanıldığı tespit edilmiş; diğer sektörlere oranla sanayi faaliyetlerini sembolize eden figürlerin daha fazla olduğu belirlenmiş; bazı logoların şehir kimliğini tam olarak yansıtmadığı ileri sürülmüştür. Yıldırım (2018: 388) tarafından Samsun ili belediye logolarındaki coğrafi semboller analiz edilmiştir. Biri büyükşehir, 17'si ilçe belediyesi olmak üzere 18 logoda, yer yer hatalı değerlendirmeler yapılmakla birlikte (tütün yapraklarının ağaç yaprağı olarak değerlendirilmesi gibi), 34'ü fiziki coğrafya, 30'u beşeri coğrafi özelliklerini sembolize eden toplam 64 unsur kullanıldığ tespit edilmiş; alanın tanıtımını yapma adına daha fazla unsur kullanma isteğinin bu çeşitliliğe neden olduğu ileri sürülmüştür. Türkan (2018: 164) tarafından Çankırı belediye logoları analiz edilmiş; az nüfuslu belediyelerde doğal çevre unsurlarına daha fazla yer verildiği belirtilmiştir. Aliağaoğlu ve Uğur (2018: 2357) tarafından Erzurum ili belediye logoları incelenmiştir. $\mathrm{Bu}$ logolarda beşeri unsurlar ön planda iken fiziki özelliklere de yer verildiği belirtilmiş; unsurların mitolojik anlamlarından ziyade gerçek anlamları ile kullanıldığı vurgusu yapılmıştır.

\section{Araştırma Sahasının Yeri, Sınırları ve Genel Özellikleri}

Batısında Ordu, güneyinde Sivas ve Erzincan, doğusunda Trabzon ve Gümüşhane illeri bulunan Giresun ili, Karadeniz Bölgesi’nin Doğu Karadeniz Bölümü'nde yer alır. İlin 16 ilçesinden 8 'inin (batıdan doğuya doğru Piraziz, Bulancak, Merkez, Keşap, Espiye, Tirebolu, Görele, Eynesil ilçeleri) Karadeniz'e kıyısı vardır. Bunların ilçe merkezleri kıyı boyunca uzanır. Kıyıdan itibaren Giresun Dağları olarak adlandırılan dağlık kütle yükselmektedir. İlin bu kütlenin kuzeye bakan yamaçlarında yer alan, ancak denize kıyısı olmayan 5 ilçesi (batıdan doğuya doğru Dereli, Yağlıdere, 
Güce, Doğankent ve Çanakçı ilçeleri) bulunmaktadır. Şebinkarahisar, Alucra ve Çamoluk ilçeleri ise Giresun Dağlarının güneyinde kalmaktadır (Şekil 1).

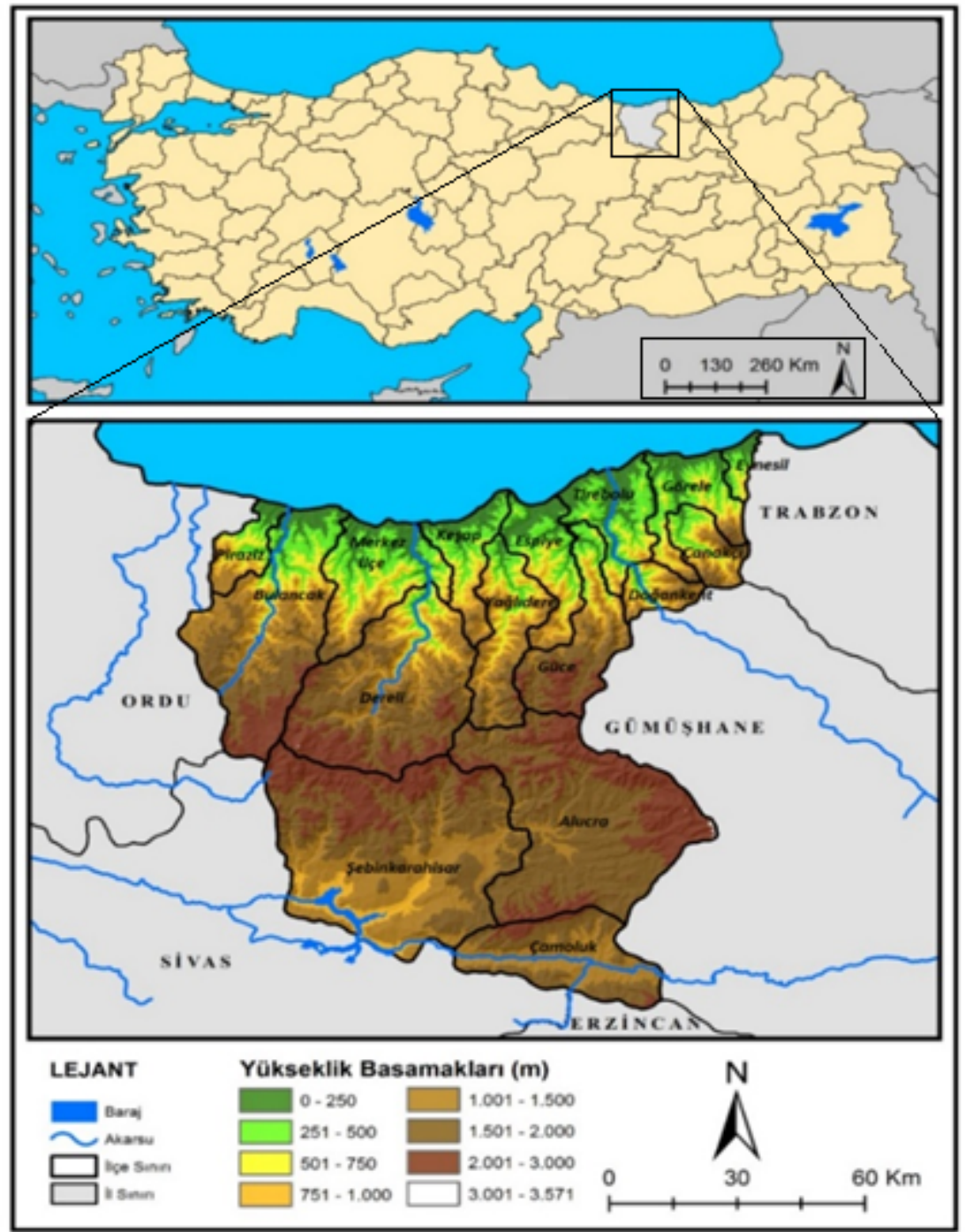

Şekil 1: Giresun İlinin Lokasyon Haritas1.

İl merkezinde yer alan meteoroloji istasyonun verilerine göre Giresun şehrinde yıllık sıcaklık ortalaması $14,5{ }^{\circ} \mathrm{C}$ 'dir. Aylık sıcaklık ortalaması ocak ayında $7{ }^{\circ} \mathrm{C}^{\prime}$ ye kadar düşmekte, temmuz ayında ise $23{ }^{\circ} \mathrm{C}$ 'ye kadar yükselmektedir. Ilık kışların, serin yazların yaşandığ 1 yörede; yağış en çok sonbahar, en az yaz mevsiminde düşmekte ve yıl boyunca görülmektedir. Kuşkusuz bu değerler kıyı kesimi temsil edebilir. Güneye, Şebinkarahisar'a doğru gidildikçe yıllık sıcaklık ortalaması azalmakta, don olağan hale gelmekte, ocak ayı sıcaklık ortalamasında düşüş görülmektedir. Yağış, Giresun Dağlarının güneyinde azalmakta, kar yağışı ve karla örtülü gün sayısı artmaktadır (Tablo 1).

Yerşekillerinde ve iklimde görülen belirgin farkl1lıklar hem doğal hem de kültüre alınan bitkilerde etkisini hissettirmektedir. Kıyıda ticari değeri yüksek findık ve çay üretilebilirken, güneye gidildikçe bu olasılık giderek azalmakta, buğday önem kazanmaktadır. Ürün desenindeki bu farklılaşma logolara da yansımıştır. 
Tablo 1: Giresun ve Şebinkarahisar'ın seçilmiş iklim verileri (1975-2011).

\begin{tabular}{lcccccccc}
\hline \multirow{2}{*}{ Aylar } & \multicolumn{2}{c}{ Ortalama Sicaklık } & \multicolumn{2}{c}{ Donlu Gün Sayısı } & \multicolumn{2}{c}{ Ortalama Yağış Miktarı } & \multicolumn{2}{c}{ Karla Örtülü Gün } \\
\cline { 2 - 8 } & Giresun & Ş.Karahisar & Giresun & Ş.Karahisar & Giresun & Ş.Karahisar & Giresun & Ş.Karahisar \\
\hline Ocak & 7,4 & $-2,3$ & 1,5 & 26,9 & 120,1 & 50,9 & 2,8 & 23,6 \\
Şubat & 7,0 & $-1,4$ & 2,4 & 23,2 & 94,7 & 51,7 & 3,6 & 22,2 \\
Mart & 8,2 & 3,0 & 0,8 & 18,0 & 91,0 & 61,3 & 1,4 & 12,4 \\
Nisan & 11,4 & 8,9 & 0,1 & 5,2 & 83,6 & 87,4 & 0,1 & 1,1 \\
Mayıs & 15,4 & 13,0 & - & 0,9 & 68,5 & 74,8 & - & 0,2 \\
Haziran & 20,2 & 16,6 & - & - & 84,2 & 42,1 & - & - \\
Temmuz & 23,1 & 19,8 & - & - & 81,7 & 13,7 & - & - \\
Ağustos & 23,4 & 20,1 & - & - & 86,9 & 8,2 & - & - \\
Eylül & 20,2 & 16,3 & - & 0,1 & 122,1 & 23,5 & - & - \\
Ekim & 16,3 & 11,1 & - & 2,0 & 175,6 & 58,2 & - & 0,3 \\
Kasim & 12,3 & 4,8 & - & 11,9 & 152,5 & 65,6 & - & 5,3 \\
Aralık & 9,4 & 0,1 & 0,5 & 21,9 & 117,3 & 54,3 & 0,9 & 16,0 \\
\hline Ylllk & 14,5 & 9,1 & 5,3 & 110,1 & 1278 & 591 & 12 & 81,1 \\
\hline Kaynak
\end{tabular}

Kaynak: DMIGGM verilerinden yararlanılarak hazırlanmıştır.

2019 ADNKS verilerine göre 448.400 olan il nüfusunun \%78,7'si (353.038 kişi) denize kıyısı olan ilçelerde ikamet etmektedir. Nüfus, ekonomik potansiyelin görece fazla olduğu kıyı ilçelerde toplanmıştır. Sanayinin arzu edilen düzeyde gelişmediği, ekonominin tarıma dayalı olduğu ilde 2006 yılında açılan üniversite ve canlanma emaresi gösteren turizm, yöre ekonomisi için umut olarak görülmektedir. Özellikle turizmden daha yüksek pay alma isteği amblem ve logo çalışmalarına önem verilmesine yol açmış; bazı belediyeler logolarında yakın zamanda değişikliğe gitmişlerdir.

\section{Amaç, Veri ve Metot}

Bu çalışmada Giresun ili logolarında kullanılan figürleri belirlemek, bunların doğal ve beşeri çevreyle ilişkisini tespit etmek, kullanılabilecek yeni figürleri önermek amaçlanmıştır. Bu kapsamda önce kurumlardan logolar temin edilmiş, içerdikleri unsurlar gruplandırılmıştır. Daha sonra logoların tasarımcılarına erişmek için belediyelerde yetkili kişilerle, genelde yazı işleri müdürleri ile iletişime geçilmiştir. $\mathrm{Bu}$ görüş̧meler neticesinde Piraziz, Giresun, Eynesil, Dereli, Yağlıdere, Güce, Doğankent, Çanakçı, Şebinkarahisar ve Çamoluk belediyelerinin logolarını tasarlayanlara ulaşılmış; bilgiler akademik çalışmada kullanılacağı belirtilerek, figürlerin tercih edilme gerekçelerini de içerecek şekilde doğrudan kendilerinden alınmıştır. Eldeki çalışma bu yönü ile literatürdeki diğer çalışmalardan ayrılmaktadır. Tasarımcısına ulaşılamayan diğer altı logoda, kullanılan figürlerin, renklerin "neyi temsil ettiği" konusunda belediye yetkililerinin ve konu ile ilgisi olduğu düşünülen yöre sakinlerinin görüşlerinden yararlanılmıştır (Tablo 2). Doküman incelemeleri ve görüşmeler ile derlenen veriler, tema analizi ile gruplandırılmıştır.

Tablo 2: Logolar ve bilgi kaynakları

\begin{tabular}{ll}
\hline Logolar & Bilgi Kaynakları \\
\hline Piraziz Belediyesi Logosu & Logoyu tasarlayan Murat Deniz ALADDİNOĞLU \\
Giresun Belediyesi Logosu & Logoyu tasarlayan Semih Akın TOZLU \\
Eynesil Belediyesi Logosu & Logoyu tasarlayan Erdoğan KÜÇÜKAL \\
Dereli Belediyesi Logosu & Logoyu tasarlayan Muhsin KILÇÇETIN \\
Yağlidere Belediyesi Logosu & Logoyu tasarlayan Ekrem ÖZDEMİR \\
Güce Belediyesi Logosu & Logoyu tasarlayan Kadir KARA \\
Doğankent Belediyesi Logosu & Logoyu tasarlayan Ayşe GİRGİN BARSBAY \\
Çanakçı Belediyesi Logosu & Logoyu tasarlayan Gökhan ALTIYAPRAK \\
Şebinkarahisar Belediyesi Logosu & Logoyu tasarlayan Tacettin ÇELİK \\
Çamoluk Belediyesi Logosu & Feyyaz ÇOBAN ile birlikte logoyu tasarlayan Murat DAĞITMAÇ \\
Bulancak Belediyesi Logosu & Fatih Serdar DOĞAN (Bulancak Belediyesi Yazi İşleri Müdürü) \\
Keşap Belediyesi Logosu & Ali Nuri ANIL (Kültür ve Sosyal İşler Müdürü) \\
Espiye Belediyesi Logosu & Engin BAHADIR (Espiye Belediyesi Yazi İşleri Müdürü) \\
Tirebolu Belediyesi Logosu & Mevcut logoyu revize eden Fatih Furkan AKKAYA
\end{tabular}


Görele Belediyesi Logosu

Uğur KÜBÜC (Görele Belediyesi Kültür ve Sosyal İsler Müdürü)

Alucra Belediyesi Logosu Turgut ÇITIROĞLU (Alucra Belediyesi Yazı İşleri Müdürü)

Eldeki çalışmada logolar, insan - mekân etkileşimi kapsamında, coğrafya biliminin ilkeleri dikkate alınarak değerlendirilmiştir. Bu nedenle kullanılan figürlere odaklanılmış; sanatsal ve estetik kaygılar ile kullanıma ilişkin yaklaşımlar kapsam dışı bırakılmışıı. Geometrik şekillerin (Pılıcı, 2008: 9-30), renklerin (Elliot ve Maier, 2014: 96) insanlar üzerinde psikolojik etkilerinin bulunduğu, bölgelere göre farklılıklar göstermekle birlikte renklerin bazı anlamlar içerdiğii (Gross, 2019: 212), bu nedenle amblem ve logolardaki renk ve şekillerin bilinçli tercihin ürünü olduğu ileri sürülür (Okay, 2000: 144-146; Iş1klı, 2012: 57-77; Ceylan, 2015: 315-320). Bu çalışmada renkler ve şekiller, mekân özellikleri kapsamında değerlendirilmiş; renk ve şekillerin var olduğu ileri sürülen psikolojik etkileri de kapsam dışı bırakılmıştır.

\section{Bulgular:}

\section{Belediye Logoları, Kullanılan Figürler ve Anlamları}

\section{1. Kıyı Kesimde Yer Alan Belediyelerin Logoları}

1. 1. 1. Piraziz Belediyesi Logoları: Giresun ilinin batı sınırında ve Karadeniz kıyısında yer alan belediyenin logosu 2016 yılında değiştirilmiştir. Fındık yaprağı şeklinde tasarlanan, bu yönü ile diğerlerinden ayrılan eski logoda ad ve kuruluş tarihi ile güneş, findık, hilal ve deniz figürleri bulunmaktadır (Şekil 2). Logodaki hilal yöre insanının inancını simgelemektedir. Doğan güneş figürü ile ilçenin gelişme potansiyeline vurgu yapılmakta; merkezdeki findık figürü ile ürünün yöre ekonomisindeki önemine dikkat çekilmektedir. Fındık yapră̆ının uç kısmı çadırı (otă̆ı) çağrıștırmakta, bu yönü ile göçebe Türkmen kültürüne, Çepni Türklerine atıf yapılmaktadır. Yeni logoda belediye adına, kuruluş tarihine, güneş, fındık ve denize yine yer verilmiştir. Eski logodan farklı olarak elma, türbe ve balık figürleri eklenmiştir. Elma figürü ile yakın zamanda coğrafi işaret olarak tescil edilen "Piraziz Elması", türbe figürü ile Șeyh İdris (Gökçeali Köyü’nde) ile Pir Aziz (Nefs-i Piraziz Köyü’nde) Türbeleri, balık figürleri ile balıkçılığın yöre ekonomisindeki yeri vurgulanmıştır. Yeni logoda fındık figürü küçültülmüş, denizin dalgalı hali belirginleştirilmiştir. Mavi ve yeşil çizgilerle logo çerçevesi oluşturulmuştur. Yeşil şerit ile bitki örtüsüne atıf yapılmıştır. Mavi şerit ile renk uyumu sağlamanın amaçlandığı, ilçe sınırını oluşturan Abdal Suyu'na atıf olmadığı, tasarımcısı Murat Deniz ALADDİNOĞLU tarafindan ifade edilmiştir.
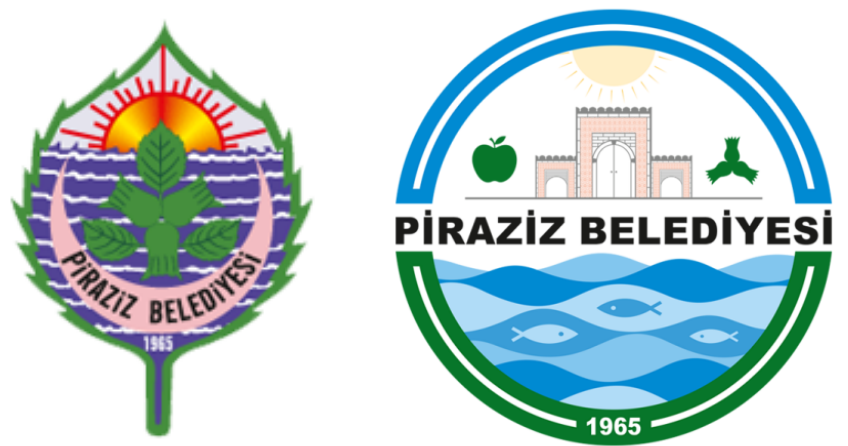

Şekil 2. Piraziz Belediyesi’nin eski ve yeni logoları.

1. 1. 2. Bulancak Belediyesi Logosu: Logoda belediye ad ve kuruluş tarihinin yanı sıra bulutlu gökyüzü, fındık, onun önünde BULANCAK yazısı, altında koyu mavi renkli ve dalgalı deniz figürü bulunmaktadır (Şekil 3). Fındık figürü, BULANCAK yazısı ve deniz arasına konumlandırılmıştır. Bu diziliş ile ilçe merkezini oluşturan yerleşmenin, findık bahçeleri ve deniz arasında gelişme gösterdiği ima edilmiştir. Fındık çotanağı bulutlu gökyüzünde Bulancak üzerinde, güneş gibi konumlandırılmıştır. Bu ayrıntı ile de fındığın Bulancak ekonomisi için önemine dikkat çekilmiştir. 


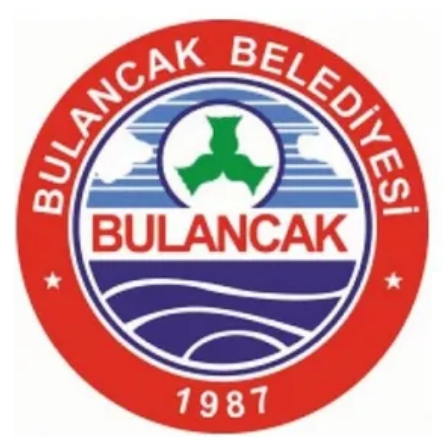

Şekil 3. Bulancak Belediyesi'nin logosu.

1. 1. 3. Giresun Belediyesi Logosu: İl belediyesi konumunda olan Giresun belediyesi, il sınırları içerisindeki en eski belediyedir ve 1869 yılında kurulmuştur. Semih Akın TOZLU tarafından tasarlanan belediye logosunda ad ve kuruluş tarihi ile dağ, ada, kale, kiraz, balık ve findık figürlerine yer verilmiştir. Bu figürler yerleşmenin güneyindeki dağlık alandan kuzeyindeki denize doğru belli bir düzen içinde sıralanmıştır (Şekil 4). En arka planda yer alan üçgen form kıyı ardındaki dağları ve aynı zamanda Doğu Karadeniz'in tek adasını temsil etmektedir. Yoğun bitki örtüsünün varlı̆̆ına dikkat çekmek amacı ile bu figür yeşil ile renklendirilmiştir. Bunun önünde üçgenin tepe noktasını örtmeyecek şekilde konumlandırılmış findık çotanağı ile alçak kesimlerde doğal bitki örtüsünün yerini findığa bırakma hali sembolize edilmiştir. Fındık önünde sur figürü bulunmaktadır. Bununla Pontus döneminde Kral Farnakos tarafindan yapıldığı kabul edilen (Bekdemir, Ertürk ve Güner, 2011: 4) ve şehir siluetinde önemli yeri olan Giresun Kalesi'ne ve dolayısı ile şehrin kadim geçmişine atıf yapılmıştır. Giresun adının kirazdan (cerasus) geldiğine (Emecen, 1996: 78), kirazın anavatanın Giresun ve çevresi olduğuna dair (Darkot, 1986: 789; Kara Düzgün, 2009: 134) görüşler vardır. Bu tezlerin etkisi ile logoda kiraz figürüne yer verilmiştir. Kale figürünün hemen önünde yer alan iki balık ile yöredeki balıkçılığa, kırmızı gözlerle ise balıkların tazeliğine atıf yapılmış; aynı zamanda renk uyumu sağlanmıştır. Fındık figürü diğerlerine oranla daha büyük çizilerek ürünün şehir ekonomisindeki yeri vurgulanmıştır.

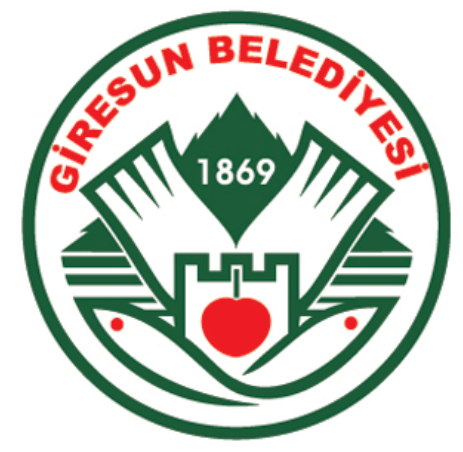

Şekil 4. Giresun Belediyesi'nin logosu.

1. 1. 4. Keşap Belediyesi Logosu: Keşap Belediyesi'nin logosunda ad ve kuruluş tarihi ile dağ, findık, testi, yelkenli kayık, balık ve deniz figürleri bulunmaktadır (Şekil 5). Arka fonu oluşturan sarı renk ile güneş imajı verilmeye, bununla da Keşap'ın gelişme eğilimine, en azından hedefine atıf yapılmıştır. Yeşil üçgen bitki örtüsü ile kaplı çevre dağlık alanı sembolize etmektedir. Fındık figürü ile findığın yöre ekonomisindeki yerine dikkat çekilmekte; yelkenli kayık ve balıklar ile yörede önemli olan balıkçılığa vurgu yapılmaktadır. Testi figürü salamura, sirke, turşu üretimi ile ilişkilendirilmektedir. Ana hatları ile $10 \mathrm{~km}$ kadar batısındaki Giresun Belediyesi'nin logosuna çok benzemekte; tekne ve testi figürlerinin varlığı, sarı rengin baskınlığ 1 , sur ile kiraz figürlerinin yokluğu ile ondan ayrılmaktadır. 


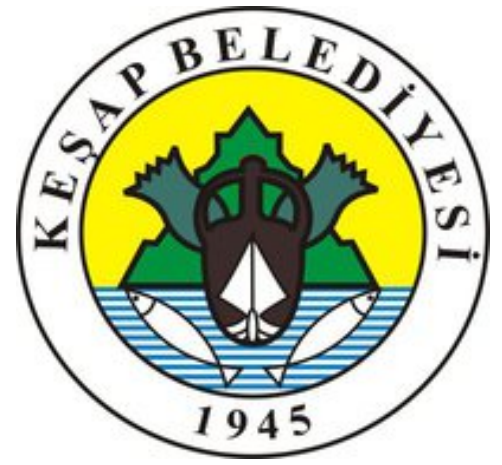

Şekil 5. Keşap Belediyesi'nin logosu.

1. 1. 5. Espiye Belediyesi Logosu: Espiye Belediyesi'nin logosunda ad ve kuruluş tarihinin yanı sıra sur, ağaç, fındık figürleri ile birbirine paralel iki yeşil hat bulunmaktadır (Şekil 6). Sur Anduz Kalesini, "E" harfine benzemesi ile de "Espiye" adını temsil etmektedir. Arka plandaki ağaç, bitkilerle kaplı dağlarını, merkezdeki iri findık figürü yöre tarımında büyük önemi olan fındık tarımını sembolize etmektedir. Espiye Belediyesi'nin batısından Yağlıdere, doğusundan Gelevera (Özlüce) dereleri denize ulaşmaktadır. İki yeşil hat hem bu akarsuları, hem de denizi temsil ediyor olabilir. Ancak tasarımcıya ulaşılamadığı, tasarım hakkında da kurumda bir kayıt bulunmadığı için bu hususta net ifadeler kullanmak güçtür.

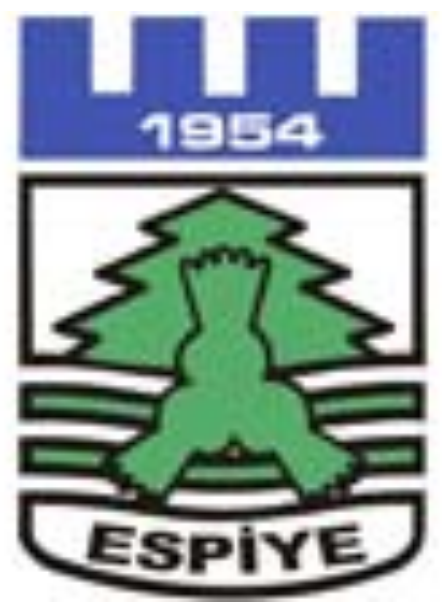

Şekil 6. Espiye Belediyesi’nin logosu.

1. 1. 6. Tirebolu Belediyesi Logosu: Tirebolu Belediyesi logosunda martı, kale, findık ve dalgalı deniz figürüne yer verilmiştir (Şekil 7). Böylelikle yerleşmenin deniz kıyısında yer aldığı, tarihi geçmişi olduğu ve ekonomisinin findık tarımına dayalı olduğu vurgulanmıştır. Denizin dalgalı sembolize edildiği kısımda mavi çizgiler arası beyaz bırakılmış; plaj özelliği gösteren kumsalların varlığına dikkat çekilmiştir. Tirebolu ve çevresinde yöreyi savunmak adına yapıldığı düşünülen biri merkezde olmak üzere üç kale (Anduz, Bedrema ve Saint Jean Kaleleri) bulunmaktadır. Birinci Dünya Savaşı esnasında da doğudan Anadolu topraklarına giriş yapan Rus ordusu Harşit savunması ile Tirebolu'da durdurulmuştur (Çelik, 2017: 155-156; Yüksel, 2017: 178). Kalkan şekli ile savunma açısından taşıdığı öneme ve özellikle Harşit Savunması'na; kırmızı renk ile de vatan savunmasında şehit düşenlere vurgu yapılmış olabileceği, logoyu orijinal figürleri koruyarak yeniden stilize eden Fatih Furkan AKKAYA tarafından ifade edilmiştir. 


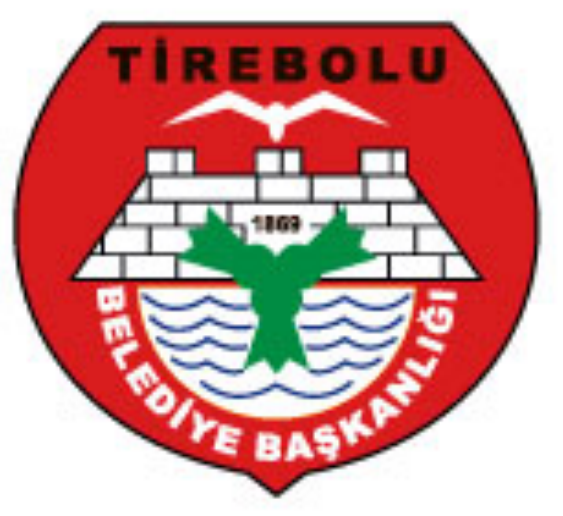

Şekil 7. Tirebolu Belediyesi'nin logosu.

1. 1. 7. Görele Belediyesi Logosu: Görele Belediyesi logosunda ad ve kuruluş tarihinin yanı sıra mavi gökyüzü, martı, deniz, bulut, hilal ve fındık figürleri ile hilali çevreleyen yeşil hat bulunmaktadır (Şekil 8). Açık mavi gökyüzü ile bulut yöre iklimini, martı figürü doğal yaşamı temsil etmektedir. Gökyüzü ile denizi ayıran hat, düz çizilmeyerek denizin dalgalı haline vurgu yapılmıştır. Hilal şeklindeki Ay, inancı ve deniz çevresinde gelişen Görele yerleşmesini temsil etmektedir. Sarı hilal arkasındaki yeşil kuşak doğal bitki örtüsünü sembolize etmektedir. Bu logoda, kıyıda yer alan diğer ilçe belediyelerinin logolarına göre findık figürü küçük çizilmiştir.

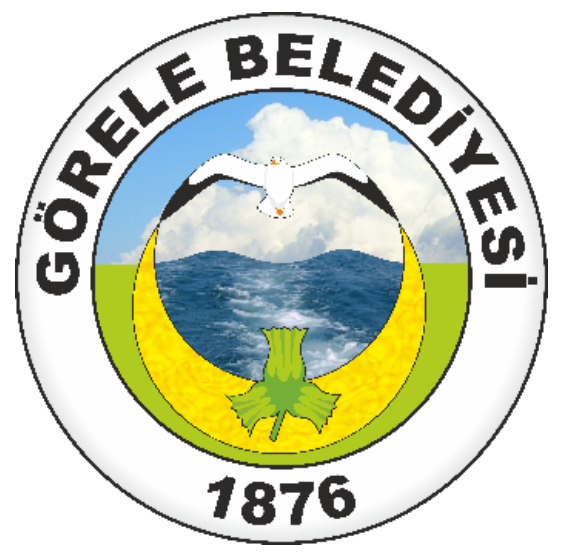

Şekil 8. Görele Belediyesi'nin logosu.

1. 1. 8. Eynesil Belediyesi Logoları: Giresun ilinin en doğudaki belediyesi olan Eynesil'in logosu 2017 yılında değiştirilmiş̧ir. Eski logoda ad ve kuruluş tarihinin yanı sıra çay, findık, balık ve deniz figürleri yer almaktadır. Çay figürü ile ilçede yaygın olan çay tarımına, balık figürü ile balıkçılığa vurgu yapılmaktadır. Bu ikisine oranla merkeze konumlandırılan ve daha büyük yapılan findık figürü ile yörede hakim ürünün findık olduğu ve ilçe ekonomisinde findığın başat rol oynadığı vurgulanmaktadır. Köpüklü, hafif dalgalı deniz ile ilçenin lokasyonu hakkında bilgi vermekte, doğal güzelliğine vurgu yapılmaktadır. Yeni logoda fındık, çay ve deniz figürleri korunmuştur. Kale, hilal ve yıldız figürleri eklenmiş; eski logodaki balık figürüne ise yer verilmemiştir (Şekil 9). Kale figürü ile Eynesil kalesine, hilal ve yıldız figürleri ile devlete, bayrağa olan aidiyete, vatan savunmasında şehit olanlara, yöre insanının inancına vurgu yapılmıştır. Logo ve amblemlerde güneş, yıldız gibi figürlere gelişme, öncü, en iyi olma gibi anlamlar da yüklenmektedir. Eynesil Belediyesi logosunda yıldız figürünün hilali tamamlamak adına kullanıldığı, ilgili figüre ayrıca bir anlam yükleme durumunun söz konusu olmadığı tasarımcısı Erdoğan KÜÇÜKAL tarafından dile getirilmiştir. 

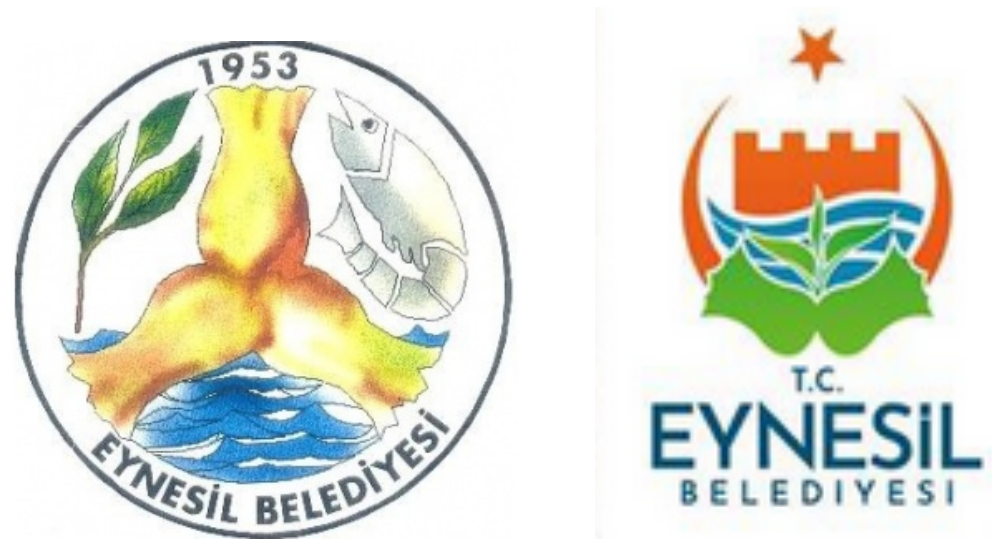

Şekil 9. Eynesil Belediyesi'nin eski ve yeni logosu.

\section{2. Kıyı ile İç Kesimler Arasında Yer Alan Belediyelerin Logoları}

1. 2. 1. Dereli Belediyesi Logosu: Dereli, ilin kıyı ile iç kesimler arasında yer alan ilçelerinden biridir. İlçe merkezi Aksu Çayı Vadisi'ndedir. Belediyenin logosunda ad ve kuruluş tarihinin yanı sıra güneş, dağ, dağlar arasında ağaç, fındık, köprü ve akarsu figürleri bulunmaktadır (Şekil 10). Yükselen güneş figürü, gelişen Dereli'yi temsil etmektedir. Dağlar çevre yerşekillerini, bunların yeşile boyanması ve aradaki ağaç, çevredeki gür bitki örtüsünü sembolize etmektedir. Merkezdeki fındık figürü ile ürünün yöre tarımında ve ekonomisindeki önemi vurgulanmıştır. Tek gözlü köprü figürü ilçe merkezindeki tarihi köprüyü; bu gözden akan su ise yerleşmeyi ikiye ayıran Aksu Çayı'nı temsil etmektedir. Figürleri çevreleyen dairenin alt kısmındaki dişli çark genelde sanayi şehirlerinde karşımıza çıkmaktadır. İlk etapta Giresun Belediyesi sınırları içerisinde kalan ancak günümüze ulaşmayan Aksu Kağıt Fabrikasına atıf yapıldığı düşünülmüştür. Ancak tasarımcısı Muhsin KILIÇÇETINN, dişli çark figürünü kurumun sürekliliğini, düzenini, belediyenin hizmet anlayışını temsil için logoya yerleştirdiğini ifade etmiştir.

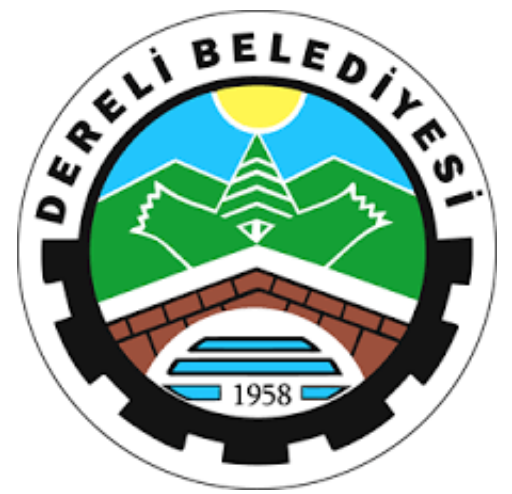

Şekil 10. Dereli Belediyesi’nin logosu.

1. 2. 2. Yağlıdere Belediyesi Logosu: Ekrem ÖZDEMIR tarafından tasarlanan logoda akarsu, kivi, findık, kemer köprü ve ağaç figürlerine yer verilmiştir (Şekil 11). Akarsu figürü "Y" harfi şeklinde stilize edilerek hem derenin hem de belediyenin "Yağlıdere" adına atıf yapılmıştır. Kemer köprü ile Yağlıdere vadisindeki kemer köprüler ve yörenin tarihi geçmişi vurgulanmıştır. Bu logoda fındık figürü merkezden yana kaymış, boyutu da küçülmüştür. Giresun ilinde ilk kivi bahçesi Yağlidere ilçesinde oluşturulmuş, ürün ilk kez bu ilçede hasat edilmiştir. Kivi figürü ile hem bu duruma, hem de belediyenin kivi tarımı ile markalaşma isteğine atıf yapılmıştır. Logoda yer alan diğer figürler ise ağaçlardır. Bunlar piramidal yapılı tasvir edilerek yörede iğne yapraklı ağaçların daha yoğun olduğu ima edilmiştir. Ayrıca hem logo zemininde, hem de logoyu çevreleyen çizgilerde yeşil renk kullanılarak yörenin gür bitki örtüsüne vurgu yapılmıştır. 


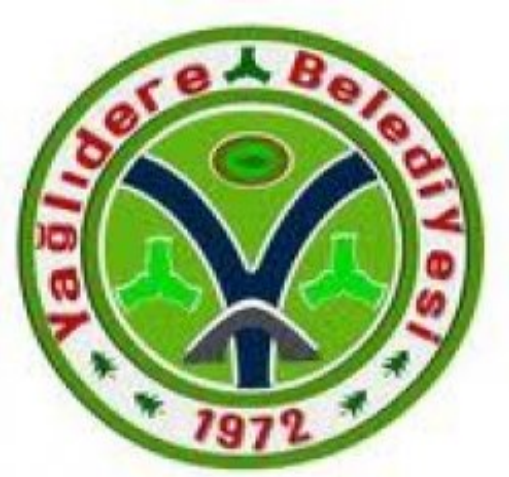

Şekil 11. Yağlıdere Belediyesi’nin logosu.

1. 2. 3. Güce Belediyesi Logosu: Güce ilin az nüfuslu olan ve yeni kurulan ilçelerinden biridir. Bu ilçenin idari merkezi olan Güce Belediyesi'nin logosunda ad ve kuruluş tarihi ile dağ, akarsu, ağaç, çay ve fındık figürleri bulunmaktadır (Şekil 12). Çay ve findık figürleri ile bu ürünlerin ilçe ekonomisindeki önemi vurgulanmıştır. Ağaçlar, piramidal yapılı çizilerek yöredeki iğne yapraklı ağaçlara atıf yapılmıştır. Akarsu figürü ile ilçe merkezinden geçen Gelevera Deresi; dağ figürleri ile belediye ve çevresinin arazi yapısı tasvir edilmiştir. Yine bu dağ figürleri ile Güce yaylalarına, yöredeki yaylacılık kültürüne atıf yapıldığı tasarımcısı Kadir KARA tarafından ifade edilmiştir.

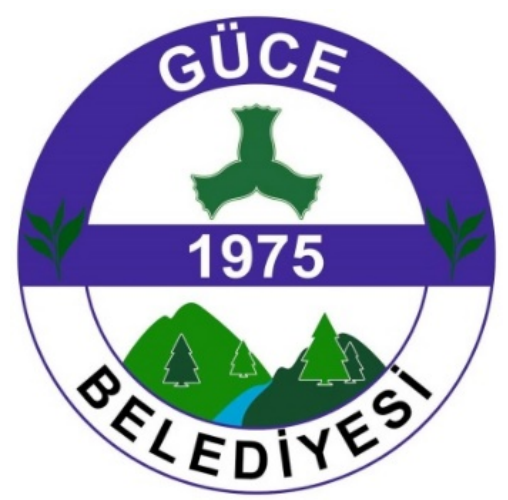

Şekil 12. Güce Belediyesi’nin logosu.

1. 2. 4. Doğankent Belediyesi Logoları: Doğankent Belediyesi'nin logosu, yarışma düzenlenerek sekiz yıl önce değiştirilmiştir. Eski logoda ad ve kuruluş tarihinin yanı sıra "d" ve "b" harfleri; üzerinden su taşan gölet seddi ve findık figürü bulunmaktadır. "d" ile "Doğankent" ismi, "b" ile "belediye" kelimesi ifade edilmek istenmiştir. Her iki harfin sap kısımlarından aşağ 1 inen mavi çizgiler hidroelektrik santraline su taşıyan cebri boruları, set ise baraj gölünü sembolize etmektedir. Diğer logoların aksine findık figürü küçük çizilerek, buna karşılık hidroelektrik santrali ön plana çıkarılarak, santralin belediyenin kuruluşunda ve ekonomisindeki önemine atıf yapılmıştır. Ayşe GIRGIN BARSBAY tarafından tasarlanan yeni logoda "Doğankent" ve "Belediye" kelimelerini ifade etmek için, yine " $D$ " ve "b" harfleri kullanılmıştır. Bu tasarımda " $D$ " harfine ayrıca "dağ" anlamı da yüklenmiş, "b" harfi bunun içerisine yerleştirilerek, yerleşmenin dağlar arasında kaldığı vurgulanmıştır. İç fındık figürü logonun merkezine yerleştirilerek, ürünün yöre ekonomisindeki önemine dikkat çekilmiştir (Şekil 13). Hepsi birlikte düşünüldüğünde çark görüntüsü veren üçgenler ile ilçe merkezindeki elektrik santraline atıf yapılmıştır. Yeşil üçgen ile gür bitki örtüsü, mavi üçgen ile Harşit Çayı ve Çatalağaç şelalesi ima edilmiştir. Lacivert üçgenler ile kurumsal kimlik vurgusu yapılmış; logoya estetik görünüm kazandırılmıştır. 

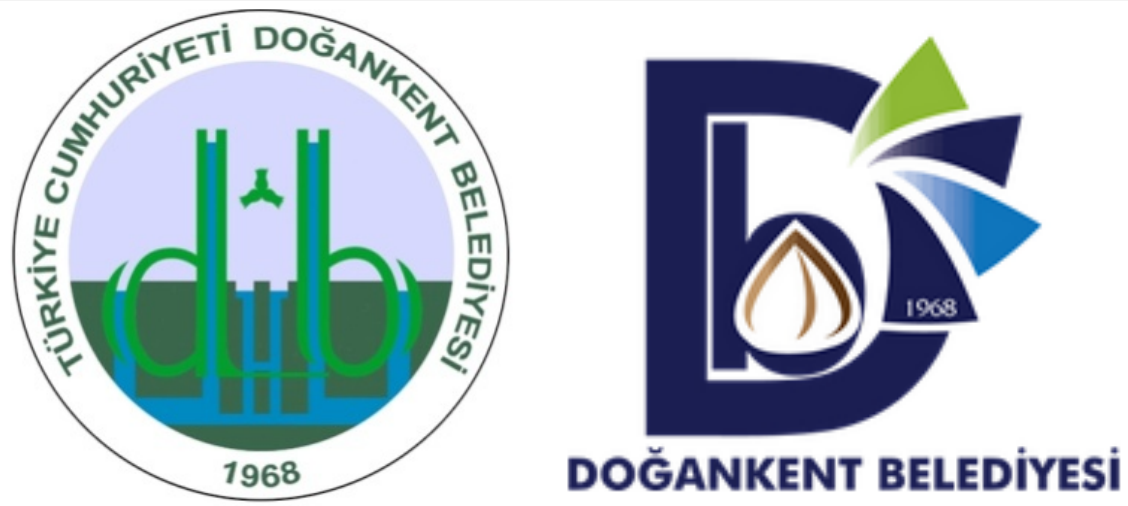

Şekil 13. Doğankent Belediyesi’nin eski ve yeni logosu.

1. 2. 5. Çanakçı Belediyesi Logoları: Çanakçı, logosu yakın zamanda değiştirilen (2017 yılında) az nüfuslu belediyelerinden biridir. Eski logosunda ad ve kuruluş tarihinin yanı sıra güneş, karlı dağ, fındık ve dere figürü bulunmaktadır. Güneşin doğuş anı resmedilerek ilçenin yeni kurulan ilçelerden biri oluşu vurgulanmıştır. Dağlar ile Sis Dağı'na, dere ile Görele Deresi'ne, findık ile yöredeki hâkim fındık tarımına atıf yapılmıştır. Çoğunda olduğu gibi bu logoda da findık merkeze alınmış ve büyük çizilmiş; böylelikle ilgili ürünün yöre ekonomisindeki önemi yansıtılmıştır. Düzenlenen yarışma sonrasında kabul edilen ve kullanılmaya başlanan yeni logo Gökhan ALTIYAPRAK tarafından tasarlanmıştır. Belirgin bir figür içermemekte, sade ve modern görünümü ile ilin diğer belediye logolardan ayrılmaktadır. Kavisli çizgiler ile oluşturulan "Ç" harfi ile belediye adı çağrıştırılmıştır. Kalın mavi hat ile ilçe merkezinden geçen Görele Deresi stilize edilmiştir (Şekil 14). Yeşil hale ile bitki örtüsüne değil de yerleşmeye atıf yapıldığı, tasarımcısı tarafından ifade edilmiştir.
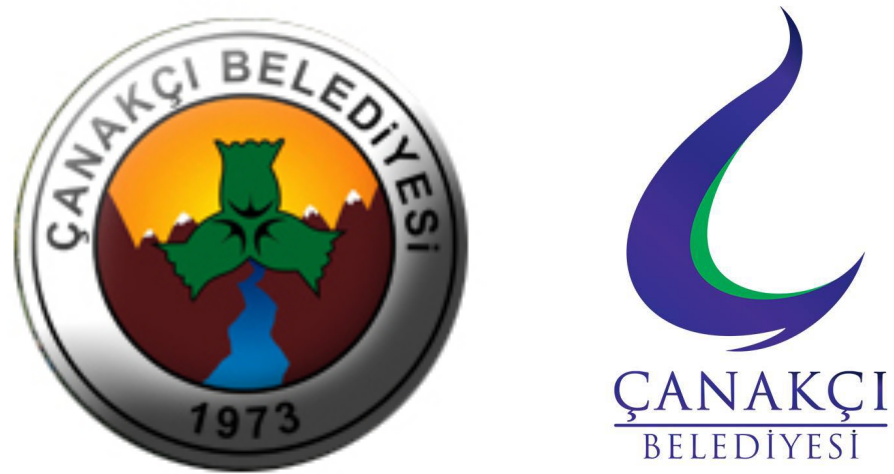

Şekil 14. Çanakçı Belediyesi'nin eski ve yeni logosu.

\section{3. İç Kesimlerde Yer Alan Belediyelerin Logoları}

1. 3. 1. Şebinkarahisar Belediyesi Logosu: Şebinkarahisar Belediyesi’nin logosu, üzerinde hisar silueti bulunan dağ, belediye adı ve kuruluş tarihinden ibarettir (Şekil 15). Oldukça sade olan logoda hisar figürü ile Şebinkarahisar Kalesi'ne atıf yapılmıştır. Şebinkarahisar kelimesi kale eteğine yazılarak, yerleşmenin kale eteğinde geliştiği vurgulanmıştır. Logoda lacivert rengin baskın olarak kullanılması dikkat çekmektedir. Yapılan görüşmede tasarımcısı Tacettin ÇELIK, bu renk ile doğal ve beşeri çevreye dair bir ima olmadığını, logoya kurumsal kimlik kazandırmak amacı ile bu rengin tercih edildiğini ifade etmiştir. 


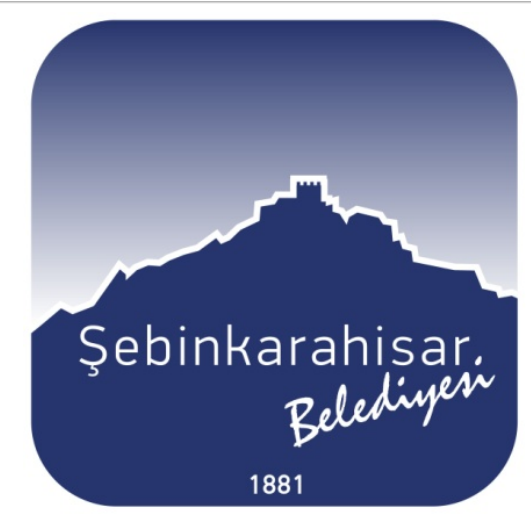

Şekil 15. Şebinkarahisar Belediyesi'nin logosu.

1. 3. 2. Alucra Belediyesi Logoları: Alucra Belediyesi'nin logosu dört yıl önce değiştirilmiştir. Eski logo ad ve kuruluş tarihini içermektedir. Alucra'nın baş harfi olan " $A$ " harfini çağrıştıracak şekilde stilize edilmiş piramidal ağaç ve onun gövde kısmını oluşturacak konumda çizilmiş olan " $\mathrm{B}$ " harfi ile ana figür oluşturulmuştur. Bu logoda açık mavi zemin gökyüzünü, " $\mathrm{B}$ " harfi "Belediye" kelimesini, ağacı çevreleyen beyaz hale ise kışın eksik olmayan kar örtüsünü ifade etmektedir (Şekil 16). Yeni logoda belediye adı ve kuruluş tarihi varlığını korumuştur. Kuruluş tarihinin değişmesi, bir çeyrek asır kadar öne çekilmesi dikkatlerden kaçmamaktadır. Bu, kuruluş tarihi ile ilgili yeni belgelere ulaşılmasının, yeni bilgiyi duyurma, vurgulama, yayma isteğinin ve nüfus kaybeden yörede köklü geçmişin önemsenmesinin sonucudur. Logonun merkezinde bal peteği şeklinde Alucra ilçe haritası, çevresinde ise buğday başakları bulunmaktadır. Bu figürler ile arıcılığa, nitelikli olduğu iddia edilen Alucra balına, yörede hâkim tarım ürününün buğday olduğuna dikkat çekilmiştir. Olgunlaşmış buğday başaklarının mavi-yeşil sapları ile ilçe merkezinden geçen Bağırsak Deresi'ne ve çevredeki bitki örtüsüne vurgu yapılmıştır. Logoda renk uyumunu sağlamak için "ALUCRA BELEDIYYESİ” kelimeleri de mavi renkte yazılmıştır.
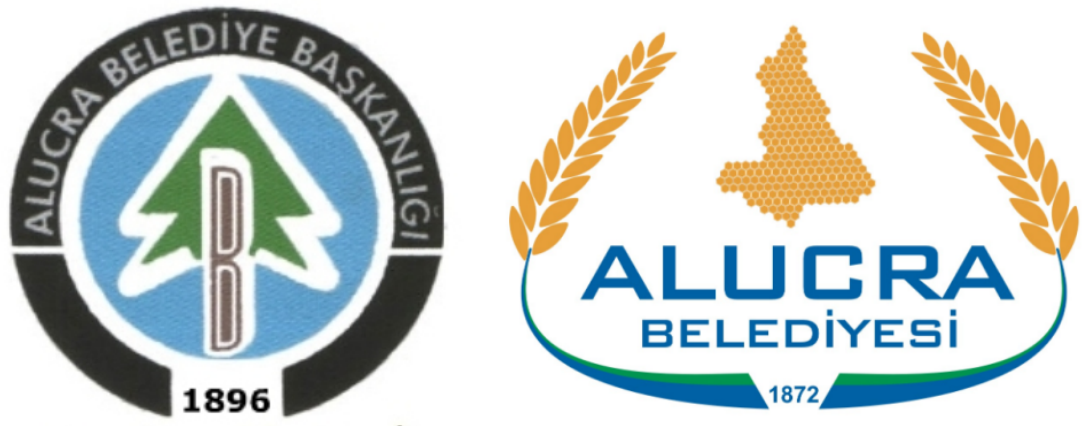

Şekil 16. Alucra Belediyesi’nin eski ve yeni logosu.

1. 3. 3. Çamoluk Belediyesi Logoları: Az nüfuslu bu ilçe belediyesinin logosu 2015'te, belediye halkının onayına sunularak değiştirilmiştir. Eski logoda belediyenin adı yazmakta, bunu "Ç" harfini anımsatan yeşil hale kuşatmakta, hale içerisinde dağ ve ağaç figürü bulunmakta idi. "Ç" harfi ile belediye adına; dağ figürü ile yörenin dağlık yapısına, ağaç figürü ile çevredeki çam ağaçlarına vurgu yapılmakta idi. Altıgen formundaki yeni logo renk ve şekil olarak bal peteğini çağrıştırmaktadır. Bu yönü ile arıcılığa atıf yapılmıştır. Logonun merkezi kısmındaki ağaç (Çam ağacı) ile hem ilçe ile belediyenin adına hem de yöredeki bitki örtüsüne atıf yapılmıştır. Çam ağacının köklerinin temas ettiği beyaz renkli kavisli hat ile ilçe merkezinin ortasından geçen, yöreye hayat veren Kelkit Çayı stilize edilmiştir (Şekil 17). Ağaç figürünün yeşil, akarsu figürünün ise mavi ile gösterilmemiş olması dikkat çekmektedir. Feyyaz ÇOBAN ile birlikte logoyu tasarlayan Murat 
DAĞITMAÇ yapılan görüşmede, hem renk karmaşasını önlemek, hem görselliği ön plana çıkarmak; hem de baskı maliyetini azaltmak adına beyaz rengi tercih ettiklerini ifade etmiştir.
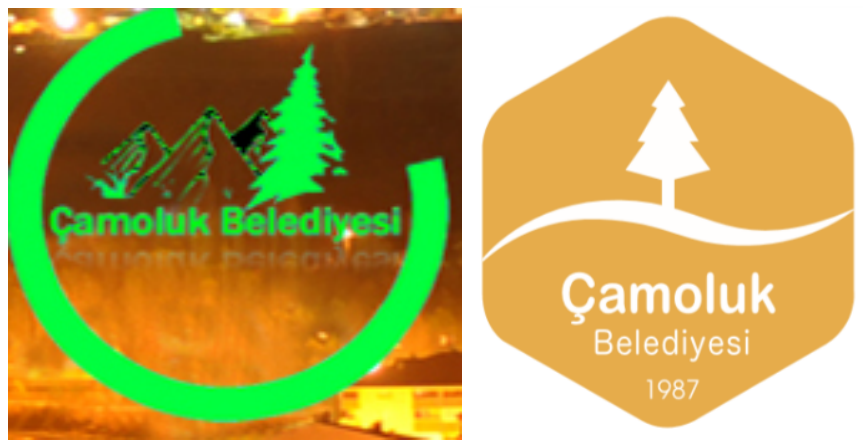

Şekil 17. Çamoluk Belediyesi'nin eski ve yeni logosu.

\section{Logolarda Kullanılan Figürler}

16 logoda, 26 farklı figür, toplamda 74 kez kullanılmıștır. Bunlar içerisinde en çok tekrar edilenler findık (12), deniz (7), akarsu (7), dağ (5), ağaç (5) ve kale (5) figürleridir. Ada, türbe, testi, kivi, elma, kiraz, buğday, kayık ve ilçe haritası ise sadece 1 logoda tercih edilmiştir (Tablo 3).

Giresun ili belediye logolarında jeomorfolojik özellikleri çağrıştıran üç figüre (dağ, vadi ve ada) yer verilmiştir. İl genelinde kıyıdan itibaren yükseklik artmaktadır. Kıyıda, akarsu vadisinde ve dağların güneyinde yer alan ilçe merkezlerinde dağlar manzarayı tamamlamaktadır. Giresun, Keşap, Dereli, Güce ve Şebinkarahisar belediyelerinin logolarında, stilize edilmiş dağ figürleri, Doğankent Belediyesi logosunda ise "D" harfi ile bu görünüme atıf yapılmıştır. İç kesimlerde yer alan Dereli ve Güce belediyelerinin logolarında dağ figürleri, merkezi kısımlarından akarsu geçirilerek iki parçalı olarak stilize edilmiş, böylelikle vadilere vurgu yapılmıştır. Giresun şehrinin bir mil kadar açığında, yaklaşık 40 dönümlük alana sahip, üzerinde bir manastır kalıntısı bulunan (Örenç, 2009: 40-41), Doğu Karadeniz'in tek adası olan (Darkot, 1986: 789) Giresun Adası bulunmaktadır (Fotoğraf 1). Logolarda atıf yapılan bir diğer morfolojik birim de bu adadır.

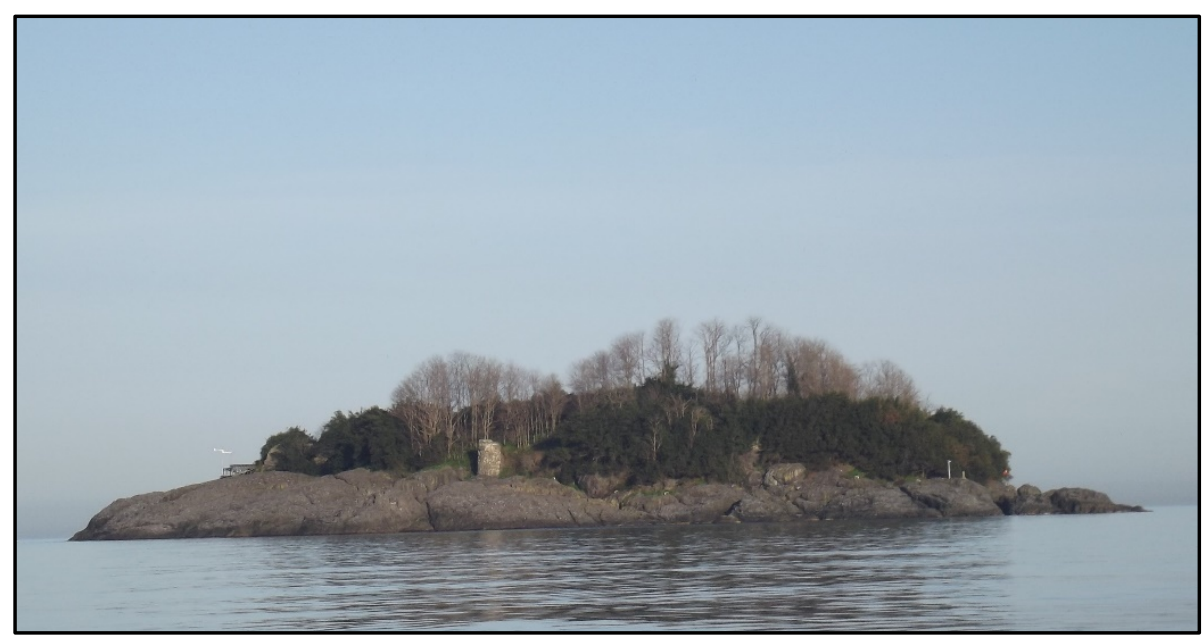

Fotoğraf 1. Giresun Adası’ndan bir görünüm.

Giresun ili belediye logolarında iklim özelliklerini çağrıştıran iki figüre (güneş ve bulut) yer verilmiştir. Güneş, Piraziz ve Dereli belediyelerinin logolarında kullanılmıştır. Karakteristik Karadeniz ikliminin görüldüğü, dolayısı ile güneşli gün sayısının görece az olduğu yerlerde kullanılan bu figür, yörenin iklim özelliklerini yansıtmaktan uzaktır. Ancak güneş figürüne yüklenen 
diğer anlamlar (yeni kurulan belediye olması, gelişme hedefi vb.), logodaki varlığının eleştirilmesini engellemektedir. Kıyı kesimde genel olarak bulutluluk fazladır. İl genelinde sadece Bulancak ve Görele belediyelerinin logolarında bu duruma atıf yapılmıştır. Yöre iklimine ilişkin bu doğrudan betimlemelere ek olarak, dolaylı ifadelerde bulunmaktadır. Piraziz, Bulancak, Tirebolu, Görele ve Eynesil logolarında deniz, dalgalı çizilmiş; yörede etkili olan rüzgârlar çağrıştırılmıştır.

Giresun ilinde kıyıdan itibaren 700 m’ye kadar doğal bitki örtüsü tahrip edilmiş, eğim derecesi çok yüksek alanlar hariç, arazi fındık bahçelerine dönüştürülmüştür (Erinç, 1945: 123). Devamında 1250 m'lere kadar yayvan yapraklı, 1250-1600 m arasında karışık, 1600-2000 m arasında ise iğne yapraklı orman örtüsüne rastlanır (Erinç, 1945:131). Yörenin orman bakımından zengin oluşuna Keşap, Espiye, Dereli, Yağlıdere, Güce ve Çamoluk belediye logolarında ağaç figürü kullanılarak yer verilmiştir. Ancak geniş yapraklı ağaçların varlığına karşın, hepsinde de ibreli ağaç formunun kullanılmış olması dikkat çekmektedir. Bunların daha heybetli görünmesi ve daha kolay stilize ediliyor olması bu durumun sebepleri arasında gösterilebilir.

Yörede nem ve yağış koşulları ot, çalı ve ağaç türlerinin gelişimine imkân verdiği için, özellikle yaz yarıyılında toprăg 1 görmek neredeyse mümkün değildir. Arazi genel olarak yeşil örtü ile kaplıdır. Piraziz, Giresun, Keşap, Espiye, Görele, Dereli, Yağlıdere, Güce, Doğankent ve Alucra belediyelerinin logolarında dağ figürleri, logo zemini ve bazı unsurların çevreleri yeşil ile renklendirilerek bu görünüme atıf yapılmıştır. Altı belediyenin logosunda (Bulancak, Tirebolu, Eynesil, Çanakçı, Şebinkarahisar ve Çamoluk) doğal bitki örtüsüne atıf yapılmamıştır. Şebinkarahisar ve Çamoluk belediyelerinin logolarında ise yeşil renk hiç kullanılmamıştır.

Giresun dağlarının zirvelerinden kaynağını alan akarsular, güneyden kuzeye doğru yol kat ederek Karadeniz'e ulaşmaktadırlar. Bu dağların güneyinde ise Yeşilırmak'ın önemli kollarından biri olan Kelkit Çayı bulunmaktadır. İlçe merkezleri, ya deniz kıyısında ya da bu akarsuların vadisinde kurulmuştur. Piraziz, Bulancak, Giresun, Keşap, Tirebolu, Görele ve Eynesil logolarında deniz; Dereli (Aksu Çayı), Yağlıdere (Yağlıdere), Güce (Gelevera), Çanakçı (Görele Deresi) ve Çamoluk (Kelkit Çayı) belediyelerinin logolarında ise akarsu figürleri kullanılmıştır. Espiye (Yağlıdere ve Gelevera), Doğankent (Harşit Çayı) ve Alucra (Bağırsak Deresi) belediyelerinin logolarında ise akarsulara dolaylı olarak atıf yapılmıştır

Giresun çevresinde yerleşme tarihi M.Ö. 2000'li yıllara kadar gider. Giresun, Espiye, Tirebolu, Eynesil ve Şebinkarahisar logolarında kale; Espiye ve Yağlıdere logolarında köprü, Piraziz logosunda ise türbe figürü kullanılarak tarihi geçmişe atıf yapılmıştır (Fotoğraf 2). Giresun ve Tirebolu belediyelerinin logolarında kale figüründe 3; Espiye, Eynesil ve Şebinkarahisar belediyelerinin logolarındaki kale figürlerinde ise 4 çıkıntı-burç bulunmaktadır. Bu farklılıklar anlamdan ziyade estetik kaygıların eseridir.

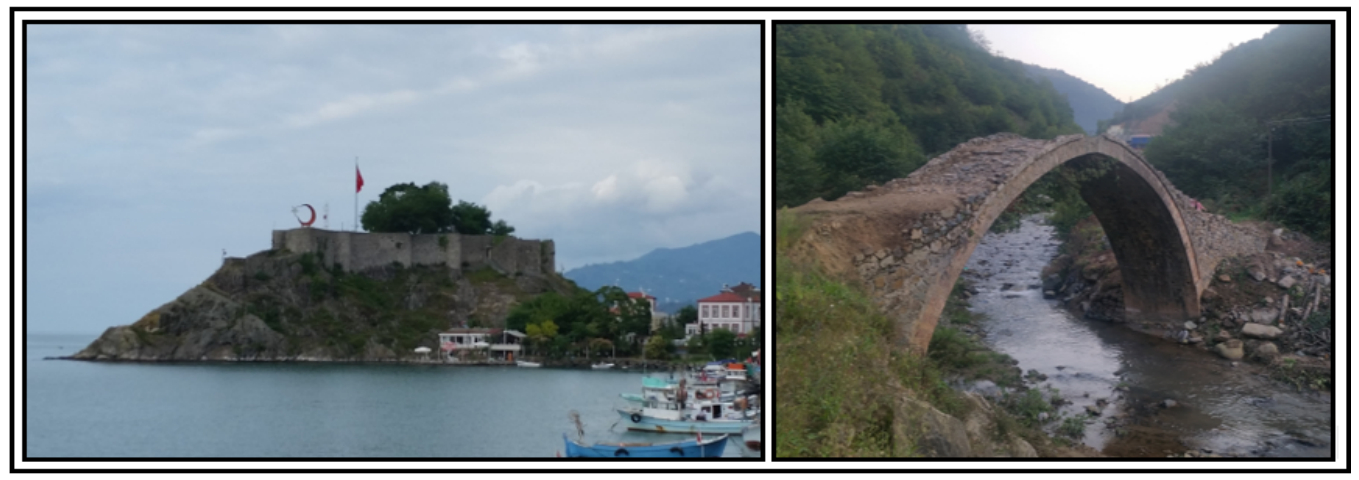

Fotoğraf 2. Saint Jean Kalesi (Tirebolu) ve Hisarc1k Köprüsü (Yağlidere). 
Giresun ili ekonomisinde sanayiye kıyasla tarım sektörü daha ön plandadır. Bu durum logolara yansımış, kullanılan çok sayıda tarım ürününe karşıllık, sanayi sektörünü çağrıştıracak hiçbir unsura yer verilmemiş̧tir (Tablo 3). Giresun ili, fındık üretiminde hem miktar, hem de kalite olarak ülke genelinde önde gelmektedir. Ayrıca fındık, diğer sektörler genel olarak gelişmediği için Giresun ekonomisinde hayati önem taşımaktadır. Bunların bir yansıması olarak Piraziz, Bulancak, Giresun, Keşap, Espiye, Tirebolu, Görele, Eynesil, Dereli, Yağlıdere, Güce, Doğankent ve Çanakçı belediyelerinin logolarında findık figürü kullanılmıştır. Hatta figür merkeze alınarak, büyük çizilerek önemi de vurgulanmıştır. Ürün Doğankent belediyesi logosunda iç findık; Giresun, Keşap, Eynesil ve Dereli belediyesi logolarında ikili; Piraziz, Bulancak, Espiye, Tirebolu, Görele, Güce ve Yağlıdere belediyelerinin logolarında ise üçlü çotanak olarak stilize edilmiştir. Tercihler, anlamdan ziyade estetik kaygıların eseridir.

Tablo 3: Logolarda Kullanılan Figürler

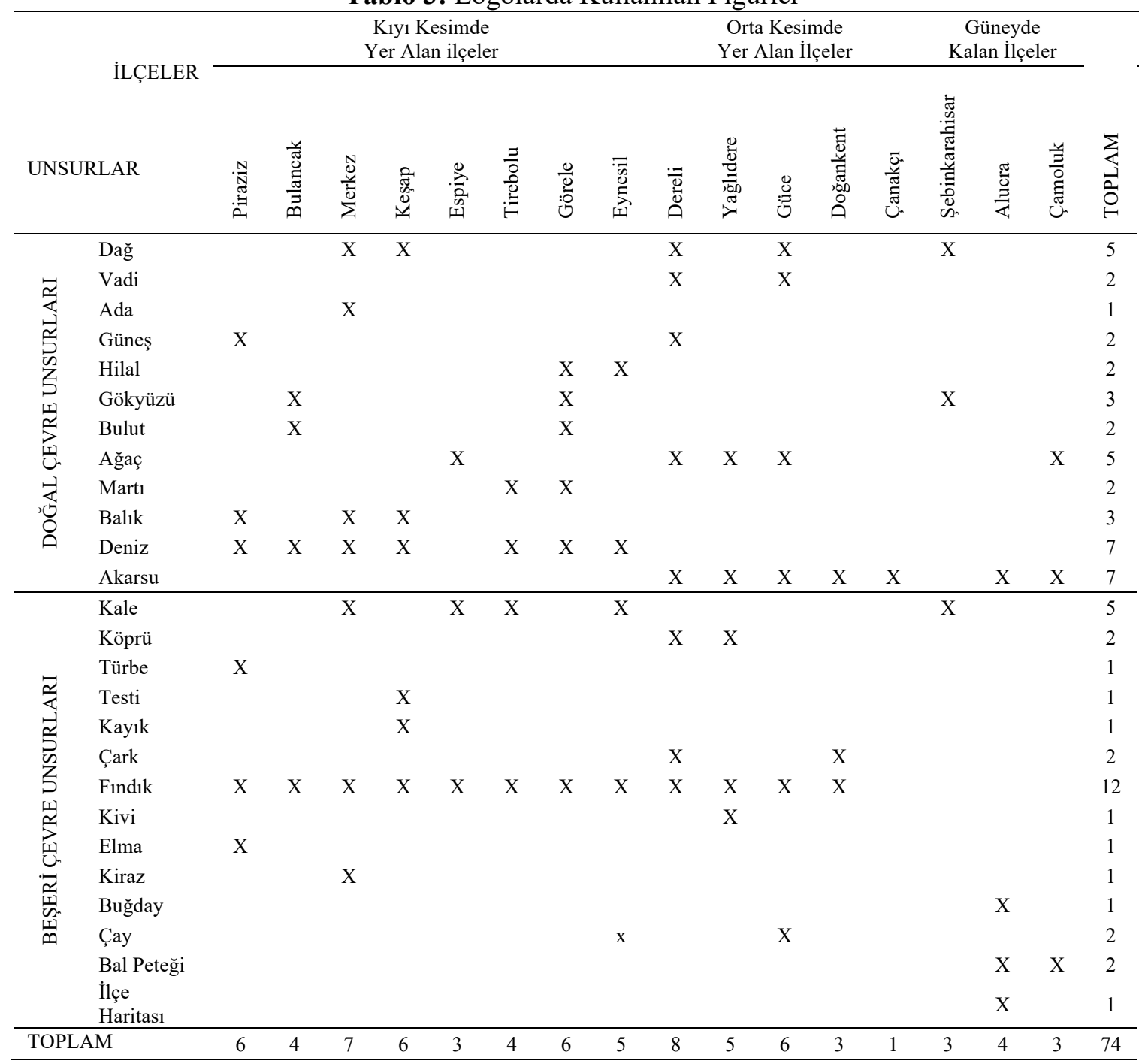

Fındık, Karadeniz Bölgesi'nde kıyıdan 60 km içeriye ve 750 m yüksekliğe kadar ekonomik olarak yetiştirilmektedir (Zaman, 2004: 56; Doğanay, 2005: 237). Bu nedenle ilde, kıyıdan iç kesimlere gidildikçe findık dikili alanların azaldığı görülür (Tablo 4). Değişim logolara yansımış; iç kesimlerdeki ilçe belediyelerinde findık figürü küçük çizilmiştir. Fındık üretimi yapılan Çanakçı 
belediyesi ile kıyı dağlarının güneyinde, findık yetişme kuşağının dışında kalan üç ilçe belediyesinin logolarında ise findık figürüne yer verilmemiştir.

Ülke sınırları içerisinde Artvin Hopa'dan, Ordu Fatsa'ya kadar çay tarımı yapılmaktadır (Doğanay, 2006: 91-92; Özcan ve Yazıcıŏlu, 2013: 67-68). Giresun ilinde Eynesil, Görele, Tirebolu, Espiye, Keşap, Güce ve Çanakçı ilçelerinde çay yetiştirilmektedir (Tablo 4). Tirebolu belediye sınırları içerisinde 1960'larda çay fabrikası kurulmuş, bu tesis belediyenin gelişimine katkı sağlamıştır. Hâlihazırda "Tirebolu 42" markası ile üretilen çay, yörede yoğun talep görmektedir. Hal böyle olmakla birlikte Tirebolu belediye logosunda hem tesisi, hem de ürünü çağrıştıracak sembol tercih edilmemiştir. Çay üretimi yapılan ilçelerden sadece ikisinin belediye logosunda (Eynesil ve Güce) çay figürüne yer verilmiştir. Bu figürlerdeki yaprak sayısı anlamdan ziyade estetik kaygıların eseridir.

Tablo 4: Giresun ili ilçelerinde toplam tarım alanı ve seçilmiş bazı tarım ürünlerinin üretim alanlarının toplam tarım alanlarına oranı (2019).

\begin{tabular}{|c|c|c|c|c|c|c|}
\hline \multirow{2}{*}{ İlçeler } & \multirow{2}{*}{ Tarım Alanı } & \multicolumn{5}{|c|}{ Üretim alanının toplam tarım alanına oranı (\%) } \\
\hline & & Findık & Çay & Kiraz & Kivi & Buğday \\
\hline Piraziz & 89575 & 97 & 0 & 0 & 0,05 & 0 \\
\hline Bulancak & 164878 & 97 & 0 & 0,01 & 0,03 & 0 \\
\hline Merkez & 205952,5 & 96 & 0 & 0 & 0,02 & 0 \\
\hline Keşap & 105975 & 95 & 0,1 & 0 & 0,06 & 0 \\
\hline Espiye & 115791 & 98 & 0,6 & 0 & 0,07 & 0 \\
\hline Tirebolu & 187500 & 91 & 3,3 & 0 & 0,03 & 0 \\
\hline Görele & 103492 & 93 & 1,4 & 0 & 0,1 & 0 \\
\hline Eynesil & 36277 & 81 & 18,5 & 0 & 0,07 & 0 \\
\hline Dereli & 83986 & 77 & 0 & 0 & 0,01 & 3,3 \\
\hline Yağlidere & 74342 & 96 & 0 & 0 & 0,17 & 0 \\
\hline Güce & 37887 & 91 & 4,9 & 0 & 0,12 & 0 \\
\hline Doğankent & 28148 & 93 & 0 & 0,01 & 0 & 0 \\
\hline Çanakçı & 29906 & 88 & 10,7 & 0 & 0,12 & 0 \\
\hline Şebinkarahisar & 130918 & 0 & 0 & 0,04 & 0 & 38,2 \\
\hline Alucra & 16210 & 0 & 0 & 0 & 0 & 45 \\
\hline Çamoluk & 11901 & 0 & 0 & 0,21 & 0 & 50,4 \\
\hline
\end{tabular}

Kaynak: TÜİK, Bitkisel Üretim İstatistikleri veri tabanından yararlanılarak oluşturulmuştur.

Kirazın anavatanının Giresun olduğu iddia edilir. Piraziz elması coğrafi işaret olarak tescil edilmiştir. İlde kivi tarımına ilk olarak Yağlıdere'de başlanmış, ürün ilk kez burada hasat edilmiştir. İlin güneyinde buğday üretimi önemlidir (Tablo 4). Logolarda üretim miktarı ve hatta ekonomik değeri az olan kiraz (Giresun), elma (Piraziz), kivi (Yağlidere) ve buğday (Alucra) figürlerinin kullanılması yukarıda özetlenen bilgileri önemseme, bunları sahiplenme ve koruma isteği ile açıklanabilir. Buna karşın yöre kültüründe önemli olan mısır, karalahana, Şebin cevizi ile coğrafi işaret olarak tescil edilen Çamoluk şeker fasulyesinin kullanılmamış olması ise dikkat çeken bir durumdur. Benzer yaklaşım sürdürülecekse, belirtilen ürünler de logolarda değerlendirilebilir.

Yöre ekonomisi ve kültüründe balıkçılık, arıcılık ve büyükbaş hayvancılık önem arz eder. Bunun bir yansıması olarak kıyıda yer alan belediyelerden üçünde balıkçılığa (Piraziz, Giresun ve Keşap), iç kesimde yer alan üç ilçeden ikisinde (Alucra ve Çamoluk) ise arıcılığa atıf yapılmıştır.

Hilal şeklindeki ay ve yıldız figürleri Görele ve Eynesil belediyelerinin logolarında kullanılmıştır. Yöre insanının inancına, vatan sevgisine vurgu yapılmış, vatan savunmasında şehit düşenler yâd edilmiştir. 
Figür çeşitliliği Dereli (8), Giresun (7), Piraziz (7), Keşap (6) ve Güce (6) belediyelerinin logolarında fazla; Espiye (3), Doğankent (3), Şebinkarahisar (3), Alucra (4) ve Çamoluk (3) belediyelerinin logolarında azdır. Çanakçı logosunda ise bir figür bulunmaktadır. Bu veriler, genel bir ifade ile kıyı belediyelerinin logolarında, iç kesimlerdeki belediyelere oranla daha fazla figür kullanıldığını göstermektedir.

Logolarda hem doğal hem de beşeri unsurlar birlikte kullanılmıştır. Bulancak (3'e 1), Giresun (4'e 3), Görele (5'e 1), Dereli (5'e 3), Güce (4'e 2), Çanakçı (1'e 0), Şebinkarahisar (2'ye 1) ve Çamoluk (2'ye 1) belediyelerinde doğal; Espiye (1'e 2), Eynesil (2'ye 3), Yağlidere (2'ye 3), Doğankent (1'e 2) ve Alucra (1'e 3) logolarında ise beşeri çevre özelliklerini yansıtan unsur kullanımı daha yaygındır. Piraziz, Keşap ve Tirebolu logolarında ise denge hali söz konusudur (Şekil, 18).

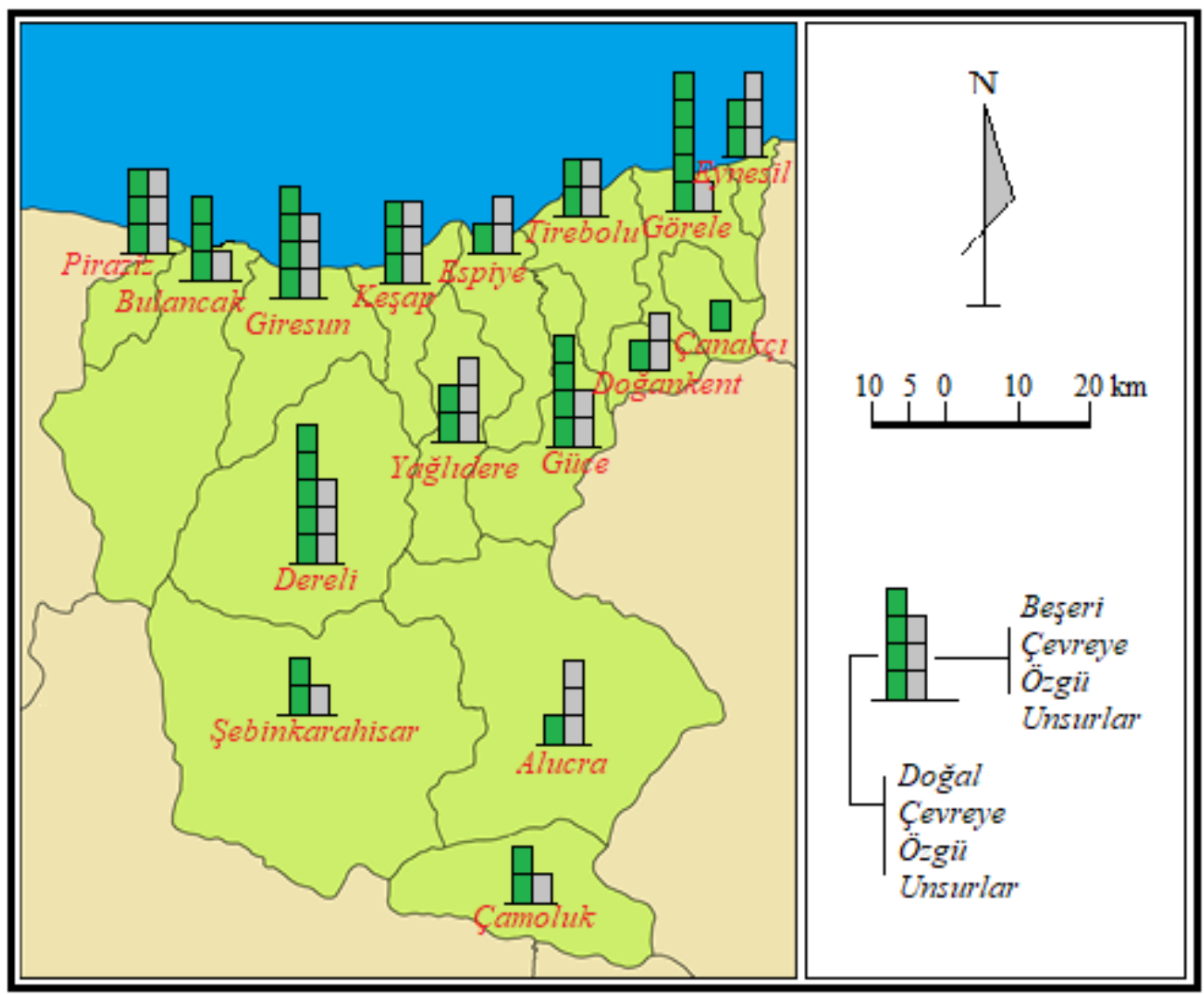

Şekil 18: Giresun ili, ilçe belediyelerinin logolarında kullanılan unsurların mekânsal dağılışı

Kullanılan figürlerin 10'u doğal, 16'sı beşeri çevre ile ilgilidir. Doğal çevre özellikleri ile ilgili 10 figürden 8'i kıyı ilçelerde kullanılmıştır. İç kesimde yer alan ilçelerde ise bu 10 figürden sadece 4'üne yer verilmiştir. Sonuç olarak, doğal çevreye özgü unsurlar denize kıyısı olan belediyelerde daha çok kullanılmıştır.

Logolarda kullanılan unsurların mekânsal dağılımı incelendiğinde ilin kıyı, orta ve güney kesiminde kalan ilçeleri arasında belirgin farkl11ıklar olduğu tespit edilmektedir. Kıyıda deniz, fındık, kale, balık ve martı kullanılırken, orta kısımda findığa ek olarak akarsu ve ağaç figürleri ön plana çıkmaktadır. Güney kesimde bitki örtüsüne atıf yapılmaması; arıcılık vurgusunun ise baskın olması dikkat çekmektedir. 


\section{Sonuç ve Öneriler}

Giresun denize kıyısı bulunan, gür bitki örtüsüne sahip olan, kültürel yapısında ve ekonomisinde fındık ve balığın önemli yer tuttuğu bir ildir. İlin bu genel yapısı logolarda karşılığını bulmuştur.

Giresun ilinde 16 belediye logosunda, 26 başlık altında toplanabilecek figürler toplamda 74 kez kullanılmıştır. Logo başına 4,6 unsur düşmektedir (Tablo 5). Bu oran daha önce yapılan çalışmalarla kıyaslandığında nispeten yüksektir. Giresun logolarında daha fazla figür kullanılması üzerinde kıyı ilçe belediyeleri arasında fiziki mesafenin az olmasının, hemen hemen hepsinde monokültür olarak aynı ürünün yetiştiriliyor olmasının, bu ürünleri sahiplenme adına aralarındaki ciddi rekabetin ve farklılaşmak adına ek ürün kullanma isteğinin rolü vardır.

Tablo 5: Coğrafyacılar tarafından logoları araştırılmış illerde, logo başına düşen unsur oranı

\begin{tabular}{lcccl}
\hline İl & Logo Sayısı & $\begin{array}{c}\text { Kullanılan Figür } \\
\text { Sayıs1 }\end{array}$ & Unsur oranı & Kaynak \\
\hline Sinop & 10 & 47 & 4,7 & Şenol ve Saraçoğlu, 2012: 340 \\
Kocaeli & 13 & 41 & 3,2 & Uzun ve Özcan, 2014: 286 \\
Samsun & 18 & 64 & 3,6 & Ylldırım, 2018: 388 \\
Erzurum & 21 & 67 & 3,2 & Aliağaoğlu ve Uğur, 2018: 2373 \\
Çankırı & 12 & 41 & 3,4 & Türkan, 2018: 163 \\
Giresun & 16 & 74 & 4,6 & - \\
\hline
\end{tabular}

Kocaeli ve Çankırı ili logolarında beşeri çevreye özgü unsurların daha fazla kullanıldığ tespit edilmiştir. Erzurum ili logolarında denge hali söz konusudur. Sinop ve Samsun logolarında olduğu gibi Giresun ili logolarında da doğal çevreye özgü unsur kullanımının yaygın olduğu görülmektedir (Tablo 6). İl genelinde markalaşmış tarihi yapı azlığ1 ve tarım dışı sektörlerin gelişmemiş olması; buna karşın olumlu imaj sunan doğal çevre özelliklerinin varlığı bu sonucun ortaya çıkmasında etkili olmuştur.

Tablo 6: Coğrafyacılar tarafından logoları araştırılmış illerin logolarında kullanılan doğal ve beşeri

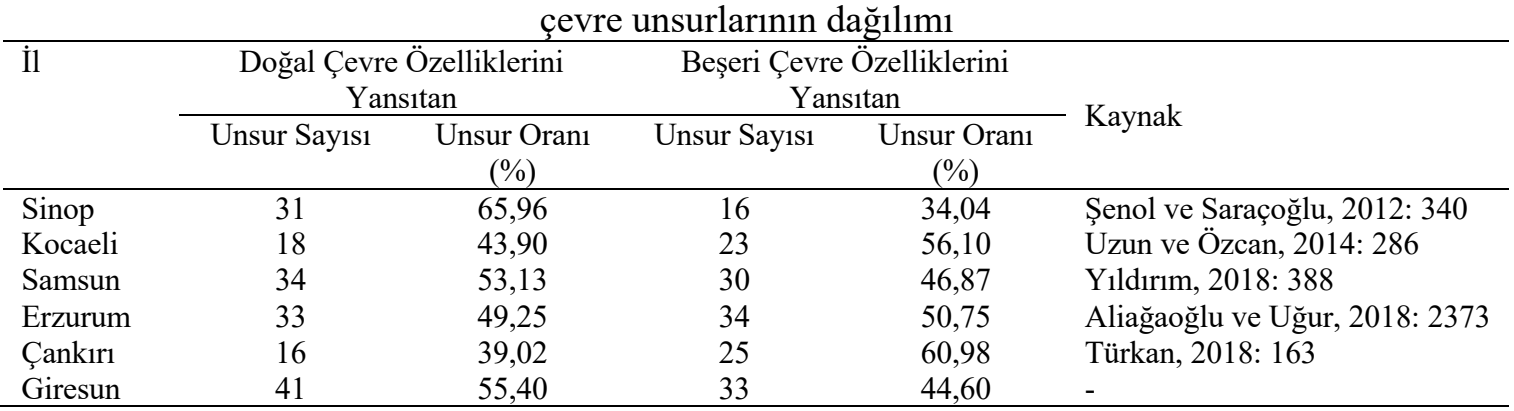

Giresun logolarında, iç kesimdeki belediyelere oranla, kıyı kesimdeki belediyelerde daha fazla unsur kullanılmıştır. Aynı durum benzer konuma sahip Samsun ve Sinop logolarında da tespit edilmiştir.

Giresun logolarında kıyı kesimdeki ilçelerde doğal çevre, iç kesimlerdeki ilçelerde ise beşeri çevreye ilişkin unsur kullanımı belirgindir. Aynı ayrım, Sinop logolarında da görülmektedir. Deniz, zihinde olumlu bir imaja sahiptir. Hem olumlu imaja sahip olduğu, hem de kolay stilize edildiği için bu unsurun tercih edilmesi, kıyı belediyelerde doğal unsurların daha baskın olmasına yol açmaktadır.

Giresun logolarında tarım ürünü kullanımı yaygındır. Kocaeli logolarında ise sanayi vurgusu daha baskındır. Bu iki örnek, ekonomik yapının logolara yansıdığını göstermektedir. Giresun ili logolarında yöre ekonomisinde etkili olan fındık şeklin merkezine alınmış, görece büyük çizilmiştir. Buna karşılık yöre kültüründe önemli yeri olan ancak ekonomik değeri az olan mısır ve karalahana gibi ürünlere yer verilmemiştir. Ekonomik değerler, kültürel değerlerin önünde yer almıştır. 
Türkan az nüfuslu belediye logolarında doğal çevre unsuru kullanımının yaygın olduğunu ileri sürmüştür (Türkan 2018: 164). Giresun ili ilçe merkezlerinden sadece beşinin (Merkez ilçe: 117.944, Bulancak: 46.198, Espiye: 24.843, Tirebolu: 20.038, Görele: 19.695) nüfusu 20.000 rakam1 civarı ve üzerindedir. Diğerlerinin nüfusu 10.000 eşik değerinin de altındadır. Nüfus miktarı az olan Dereli, Güce, Çanakçı, Şebinkarahisar ve Çamoluk belediyelerinin logolarında doğal çevre özelliklerini yansıtan unsurlar fazla iken; Eynesil, Yağlıdere, Doğankent ve Alucra belediyelerinin logolarında beşeri çevre özelliklerine ait unsurlara daha fazla yer verilmiştir. Piraziz ve Keşap ilçelerinde ise eşit dağılım söz konusudur. Bu nedenle Türkan'ın Çankırı için yaptığ 1 tespitin, Giresun için geçerli olduğunu söylemek güçtür.

Aliağaoğlu ve Uğur, Erzurum logolarında kullanılan figürlerin gerçek anlamlarında kullanıldığını, mitolojik anlam yüklenmediğini ifade etmişlerdir (Aliağaoğlu ve Uğur, 2018: 2377). Giresun ili belediye logolarında güneş, dağ, ağaç ve su figürleri yaygın olarak kullanılmış; özellikle tasarımcıların verdikleri bilgiler doğrultusunda güneş, dağ, ağaç, su kültüne ilişkin anlam yüklemesi yapılmadığı tespit edilmiştir. Bu sebeple Erzurum logoları için ifade edilen "figürlerin gerçek anlamda kullanılması, mitolojik anlam yüklenmemesi" durumunun Giresun logoları için de geçerli olduğu söylenebilir. Ancak figürler belli bir düzende sıralanarak (Bulancak, Giresun, Keşap ve Espiye logoları), önemli unsurlar merkeze konulup, görece büyük çizilerek (Bulancak, Giresun, Doğankent, Alucra), unsurlarda küçük rötuşlara yer verilerek (denizin dalgalı olması gibi) yörenin coğrafi özelliklerine yönelik imalar yapılmıştır.

Renklerin psikolojik etkilerinin olduğu, logolardaki renk seçiminde buna da dikkat edildiği ileri sürülür. Giresun ili belediye logolarında yeşil doğayı, doğal bitki örtüsünü; mavi çevredeki denizi, akarsuyu; sarı bal üretimini vurgulamak için kullanılmıştır. Giresun belediyesinin logosunda kırmızı noktalarla balığın tazeliğine vurgu yapılmıştır. Tirebolu logosundaki kırmızı renk ise kesin olmamakla birlikte Harşit savunması ve bu mücadele şehit düşenlerle ilişkilendirilmektedir. Renk uyumu sağlamak adına Giresun Belediyesi logosunda denizi sembolize eden çizgiler yeşil; Çamoluk Belediyesi logosunda ise akarsuyu temsil eden kavisli hat beyaz ile renklendirilmiştir. Dolayısı ile Giresun ili belediyelerinin logolarında renk tercihi üzerinde, subliminal mesajlardan ziyade, yörenin doğal ve beşeri özelliklerinin; ayrıca estetik anlamda renk uyumu sağlama kaygısının etkili olduğu söylenebilir.

Giresun, Doğankent, Şebinkarahisar ve Çamoluk logoları, grafik tasarım üzerine sektörde varolan, ulusal düzeyde hizmet sunan tasarımcılar tarafından üretilmiştir. Bunlar sahadan veri toplamışlar; farklı seçenekler içeren tasarımlar hazırlamışlar; talep eden kurumun yetkililerinin yaptığı telkinlerini de dikkate alarak logoya son halini vermişlerdir. Çamoluk Belediyesi, hazırlanan farklı tasarımlar için yöre sakinlerinin katılabileceği bir anket oluşturmuş, mevcut logonun tercihinde anket sonuçlarını da dikkate almıştır. Doğankent ve Çanakçı logoları için ödüllü yarışma düzenlenmiştir. Tasarımcıların daha özgür çalışma imkânı bulduğu bu sistemde logo jüri onayıyla belirlenmiştir. Piraziz, Dereli, Eynesil, Güce, Yağlıdere logoları ilgili kurum bünyesinde olan tasarımcılar tarafindan üretilmiştir. Keşap Belediyesi'nin logosu ise Kaymakamlık ve Belediye önderliğinde, ilçede görev yapan resim öğretmenlerinin de bulunduğu bir komisyon tarafindan tasarlanmıştır.

Logolar, hazırlayanların ve onu kabul edenlerin ilgili şehir hakkındaki imajlarını yansıtırlar. Temsil ettikleri belediyelerin birçok noktasında (tabelalarda, belediyeye ait araçlarda, çöp konteynırlarında, elektrik direklerinde vb.) yaygın şekilde kullanılmalarına rağmen, Giresun kamuoyunda logolara ilişkin menfi ve müspet eleştirilere pek rastlanmamaktadır. Bu, logolara karş1 kayıtsızlığın göstergesi olabileceği gibi onu kabul etme, uygun bulma anlamına da gelebilir. Bahsedilen belirsizlik nedeni ile Giresun ili belediye logolarının, yöre sakinlerinin yaşadıkları şehre ilişkin imajlarını yansıttığını net olarak söylemek güçtür. 
Logo ve amblemler, tanıtım işlevini korumakla birlikte zamanla değişmektedir (Uzuntaş ve Yazar, 2017: 99-100). Değişim üzerinde gelişen teknolojinin, okuryazar nüfustaki artışın, tasarım modalarının (akımlarının) büyük etkisi vardır. Bogdanoviç'e (1975: 143) göre şehirler büyüdükçe, başlangıçtaki sembollerin önemi azalmaktadır. Değişim kaçınılmaz olmaktadır. Hükümet (Martinez, 2006: 56), politika ve yönetim değişimi (Çalış, 2008: 41), yeni gelenin çok daha iyi, çok daha farklı fikirleri olduğunu hissettirme isteği de logolarda değişime yol açabilmektir (Papp-Vary ve Farkas, 2019: 45). Giresun ilinde son 10 yılda, özellikle az nüfuslu Piraziz, Eynesil, Çanakçı, Şebinkarahisar, Alucra ve Çamoluk belediyeleri logolarında değişikliğe gitmişlerdir. Şebinkarahisar ve Piraziz logosunun değişiminde belediye başkanı değişikliğinin etkisi vardır. Çamoluk, Çanakçı ve Doğankent logolarının değişikliği yenilik arayışı ile ilişkilidir. Logolardaki değişimi daha iyi logoya sahip olma isteği, mevcut logoyu iyileștirme çabası olarak değerlendirmek gerekir. Yeni logolarda sadeleşme söz konusudur. Tasarımlar daha özgündür. Renkler daha özenli seçilmiştir. Görele Belediyesi de benzer süreci başlatmış; logoların basılı olduğu bütün ürünlerde (araçlar, tabelalar, elektrik direkleri, çöp konteynırları vb.) yapılacak değişikliğin getirdiği mali külfet nedeni ile bu süreci şimdilik ötelemiştir. Değişiklik Yağlıdere ve Güce Belediyeleri için de önerilir. Bunlarda logo tümüyle değiştirilebileceği gibi, kurum kimliğini korumak için Bulancak, Tirebolu ve Espiye logolarında olduğu gibi revize etme seçeneği de değerlendirilebilir.

Giresun ili belediye logolarında, tipografik düzenlemeler yerine yörenin doğal ve beşeri çevre özelliklerini yansıtan resim ve figür içeren tasarımlar tercih edilmiştir. Yenileme ve revize çalışmalarında aynı yaklaşım sürdürülecekse, bölge ile ilgili araştırma yapan farklı bilim dallarına (Biyoloji, Coğrafya, Tarih, Sanat Tarihi vb.) mensup araştırmacıların bilgi birikimlerinden, eserlerinden; Giresun Üniversitesi bünyesindeki bu bölümler ile Turizm Fakültesi'nden istifade edilebilir. Ayrıca aynı üniversitenin bünyesinde Güzel Sanatlar Fakültesi de bulunmaktadır. Tasarım konusunda da ilgili fakültenin öğrenci, mezun ve öğretim üyelerinden destek talep edilebilir.

Çakmak, belediye logolarının aynı ilde yaşayanlar tarafından dahi tanınmamasını, hizmet bölgesi dışına ait unsurları içermesini, değiştirme sürecinde bazı problemler yaşanmasını, farklı yüzeylere baskı esnasında karşılaşılan sorunları vb. dikkate alarak, ülke genelindeki tüm belediyeler için altında ilgili belediyenin adının yazılı olduğu tek tip logo kullanılmasının daha uygun olacağını ileri sürmüştür (Çakmak, 2013: 1320-1321). Gerekçelerde haklılık payı bulunmakla birlikte, logoların mekân tanıtımına katkı sunma gibi faydaları da bulunmaktadır. Bu nedenle tek tip logo yerine mevcut logolara il adının ya da plaka numarasının (il adına göre logolarda daha az yer kaplar) eklenmesi daha uygun olabilir. Bu yöntemle logo, ilgili kurumun dolayısı ile temsil ettiği mekanın belli başlı özellikleri ile ülke genelinde tantımına katkı sağlayabilir. Giresun ili belediye logolarının, dolayısı ile belediyelerinin ülke genelinde tanınırlığını artırmak adına mevcut logolara "Giresun" kelimesi veya " 28 " rakamı eklenebilir.

Logolarda yerşekillerine, bitki örtüsüne, hidrografik özelliklere, yerleşme tarihine ve tarım ürünlerine yer verilmiştir. Belediyenin yaban hayatını temsil etmesi beklenmez. Bununla birlikte belediyeyi temsil etmeyen diğer doğal unsurlara yer verilirken, balık ve martı haricinde yaban hayatına ait unsur kullanılmamış olması dikkat çekmektedir. Tarihi açıdan önem taşıyan kişiliklere (örneğin Topal Osman'a), kültürel unsurlara (örneğin kemençeye, yaylacıllk kültürüne), yöresel ürünlere (Tamzara dokuması, Giresun tavası), sanayi tesislerine (Fındık, çay fabrikaları), doğal çekiciliklere (Kuzalan şelalesi), hayvancılık kültürüne de yer verilmemiştir. Coğrafi işaret olarak tescil edilen findık ve Piraziz elması logolarda kullanılırken; yine aynı şekilde tescil süreci tamamlanmış olan dondurmaya (Görele) Tamzara dokumasına (Şebinkarahisar), şeker fasulyeye (Çamoluk) yer verilmemiştir. Birçok tarımsal ürün kullanılırken yöre mutfağında yeri olan mısır ve karalahanaya, belki ülke genelinde daha çok Giresun mutfağında görülen 1sırgan, mendek vb. otsu türlere; envai çeşidi bulunan ve yaygın olarak tüketilen mantarlara; taflan, kocayemiş, hanifta (yabani çilek) gibi yabani meyvelere yer verilmemiştir. Yukarıda adı geçen ürünler logo tasarımında değerlendirilebilirler. 
Ülke genelinde birçok logoda anıtsal tarihi yapılara yer verilmiştir (Aliağaoğlu, 2007: 281282; Çakmak, 2013: 1318, Köroğlu ve Yağc1, 2018: 75). Giresun logolarında ise köprü, türbe ve kale dışı tarihi yapılara yer verilmemiştir. İlin Türk - İslam medeniyetini temsil eden marka yapı ve eser bakımından fakir oluşu bu sonucun ortaya çıkmasında etkili olmuştur.

Logolar kurumu tanıtmak, marka değere katkı sunmak için tasarlanırlar. Bu bağlamda logonun kurumu yansıtması beklenir. Belediye logolarında, belediye sınırları haricindeki unsurlara, özellikle yerşekillerine, bitki örtüsüne, yaban hayatına, tarım ürünlerine yer verilerek bu beklentinin dışına çıkıldığı görülmektedir. Benzer durum Giresun ili belediye logolarında da tespit edilmektedir. Bu yönü ile Giresun ili belediye logolarının belediye hizmet bölgesinden ziyade ilçe genelini temsil ettiği, öğretici, bilgilendiricini yönü olduğu, yer tanıtımına katkı yaptığını belgelenmekte; ancak diğer taraftan yer pazarlama ve marka oluşturma sürecinin ise henüz uzağında kaldığını kanıtlamaktadır. İlde turizmin gelişimi için çaba sarf edilmektedir. Bu kapsamda logolarda turizme hizmet edecek figür ve vurgulara yer verilmeli; ek olarak marka, maskot ve slogan üretimi için de çaba sarf edilmelidir.

Bulancak, Keşap, Espiye, Tirebolu, Görele ve Alucra belediyelerinde logolara ve bunların tasarımcılarına ilişkin kayıt yoktur. Genel olarak, ne anlama geldiği tahmin edilmekle birlikte, neleri temsil ettiği yetkilileri tarafından da tam olarak bilinmeyen bu logolar yıllardır kullanılmaktadır. Belediye kurumlarında seçim sonuçlarına bağlı olarak işgücü sirkülasyonu hızlı olmakta; bu, kurum hafızasına zarar vermektedir. Bu nedenle kurum kimliğini koruma ve aktarma sürecine katk1 sağlamak için eski-yeni logolarla ilgili arşiv oluşturulmalı, bilgiler kayıt altına alınmadır. Eldeki çalışma sürece katkı sunduğu için önem taşımaktadır.

\section{Kaynakça}

Adamus - Matuszynska, A. ve Dzik, P. (2017): "Managing Silesia visual identity through regional and local logo design". Zeszyty Naukowe Politechniki Czestochowskiej Zarzadzanie Nr 28 t. 2(27): 87-112. https://doi.org/10.17512/znpcz.2017.4.2.08

Aliağaoğlu, A. (2007). "Lakap ve logolarda Türkiye şehirleri: Anlamların coğrafyası”. Doğu Coğrafya Dergisi, 12(17): 263-290.

Aliağaoğlu, A. ve Uğur A. (2018). "Logolarda Erzurum kent kimliği: Yorumlayıcı anlamaya yönelik bir çalışma”. Atatürk Üniversitesi Sosyal Bilimler Enstitüsü Dergisi, 22(4): 2357-2379.

Aka S. T., Gülbahçe, Ö. ve Saki Ü. (2018). “2018-2019 sezonu Türkiye Futbol Süper Ligi’nde yer alan kulüplerin simgeleri üzerine bir araştırma". Turkish Studies, 13(26): 43-54. https://doi.org/10.7827/turkishstudies.14606

Arıel Mazlum, Ö. (2009). Güzel Sanatlar Fakülteleri Grafik Bölümü ögrencilerinin amblem inceleme yoluyla grafik değerlendirme becerilerinin belirlenmesi. Yayınlanmamış doktora tezi, Gazi Üniversitesi, Eğitim Bilimleri Enstitüsü.

Becer, E. (1997). İletişim ve grafik tasarım. Dost Kitabevi Yayınları.

Bekdemir, Ü., Ertürk, M., ve Güner, İ. (2011). "Giresun'un Tarihi Coğrafyası”. Doğu Coğrafya Dergisi, 6(4): 1-17.

Bilirdönmez, T. ve Şahin, C. (2019). "Doğu Karadeniz Bölgesi şehirlerinin logolarındaki tanıtıcı sembollerin analizi”. Uluslararası Sosyal ve Beşeri Bilimler Dergisi, 2(2): 38-47.

Bogdanoviç, B. (1975). "Symbols in the city and the city as symbol". Ekistics, 39(232):140-146.

Braun, E. (2008). City Marketing: Towards an Integrated Approach. Erasmus Research Institute of Management (ERIM), ERIM PhD Series in Research and Management, 142. 
Büyükçanga, M. (2003). “Konya Merkez İlçe belediye amblemleri”. Konya Kitabı Cilt IV (Editör: Caner Arabacı) içinde, 373-378, Bahçıvanlar Basım San. A.Ş.

Büyükçanga M. (2004). "Ilgın, Kadınhanı, Sarayönü, Karapınar, Hadim ilçelerinin belediye amblemleri". Konya Kitabı Cilt VII (Editör: Caner Arabac1) içinde, 403-406, Damla Ofset.

Byrom, J. W. ve Lehman, K. F. (2007). "Corporate visual identity in local government: The role of the logo". Proceedings of the 6th International Congress on Public and Non-profit Marketing (14-15 June 2007), 1-13.

Ceylan, İ. G. (2015). “Amblem ve logo tasarımlarında renklerin dili”. Süleyman Demirel Üniversitesi Güzel Sanatlar Fakültesi Sanat Dergisi (SDÜ ART-E), 8(16): 314-330. https://doi.org/10.21602/sgsfsd.27667

Çakmak, N. M. (2013). "Belediye logoları hakkında bazı düşünceler”. Gazi Üniversitesi Hukuk Fakültesi Dergisi, 17(1-2): 1315-1326.

Çalış, E. (2008). Amblem ve logo tasarımlarında yalınlaştırmalar. Yayınlanmamış yüksek lisans tezi, Süleyman Demirel Üniversitesi, Güzel Sanatlar Enstitüsü.

Çamdereli, M. (2006). “IBB logosu nasıl okunmalı?”, Reklam Arası içinde (161-192), Tablet Yayınlar1.

Çamdereli M., Varlı M., Varlı Z. ve Gürer M. (2006). "Kentsel kimlik göstergesi olarak kent logoları”. II. Ulusal Halkla İlişkiler Sempozyumu (21. Yüzyılda Halkla İlişkilerde Yeni Yönelimler, Sorunlar ve Çözümler - 27-28 Nisan 2006) Bildiriler Kitabı içinde: 235-280.

Çelik, M. E. (2017). "Birinci Dünya Savaşı'nda Harşit Savunması". Harşit Vadisi Tarih, Coğrafya, Kültür (Ed: M. Fatsa ve M. Özmenli) içinde: 153-158, ASD Grafik.

Çeliker, M. ve Tokoğlu, A. A. (2017). "Marka kent oluşturulmasında grafik tasarımın rolü ve Gaziantep Örneği”. Süleyman Demirel Üniversitesi Güzel Sanatlar Fakültesi Sanat Dergisi (SDÜ ART-E), 10(19): 136-159. https://doi.org/10.21602/sduarte.309825

Darkot, B. (1986). "Giresun Maddesi”. İslam Ansiklopedisi Cilt: IV içinde:789-790, MEB Yayınevi.

Demir, H. (2013). "Mersin'de kentsel kimlik göstergeleri olarak kullanılan logolara ilişkin bir değerlendirme", Sanat Dergisi, (22): 115-122.

Demirel, M. (2014). "Burdur kent imaj1: Mehmet Akif Ersoy Üniversitesi öğrencileri üzerine bir alan araştırmas1-Burdur”. Mehmet Akif Ersoy Üniversitesi Sosyal Bilimler Enstitüsü Dergisi, 6(10): 230-241.

Demirkol, U. (2019). Türkiye Cumhuriyeti valilik logo ve amblemlerinin tasarım elemanları, tasarım ilkeleri ve içerik açısından incelenmesi. Yayınlanmamış yüksek lisans tezi, Giresun Üniversitesi, Sosyal Bilimler Enstitüsü.

Doğanay, S. (2005). “Trabzon ilinde fındık tarımı”. Doğu Coğrafya Dergisi, 10(13): 233-252.

Doğanay, S. (2006). “Trabzon'da çay tarımının coğrafi esasları”. Doğu Coğrafya Dergisi, 11(16): 233-252.

Elliot, J. A., ve Maier, M. A. (2014). "Color psychology: Effects of perceiving color on phychological functioning in humans". Annual Reviews of Psyhology, (65): 95-120. https://doi.org/10.1146/annurev-psych-010213-115035

Emecen, F. (1996). “Giresun Maddesi”. Diyanet İslam Ansiklopedisi Cilt XIV içinde: 78-84.

Erinç, S. (1945). “Kuzey Anadolu Kenar Dağlarının Ordu- Giresun kesiminde lanşaft şeritleri”. Türk Coğrafya Dergisi, $(7,8):$ 119-140. 
Fettahlığlu, S., Yıldız, A. ve Göksu, N. (2017). "Kahramanmaraş halkının şehir pazarlaması sürecinde algısının ölçülmesi ve logo geliştirilmesine yönelik bir çalışma". Journal of Social And Humanites Sciences Research, 4(15): 1924-1936. https://doi.org/10.26450/jshsr.305

Geçikli, F. (2013). Şehir imajı: Amasya Şehri üzerine bir inceleme. Erzurum: Fenomen Yayıncılık.

Giritlioğlu, İ. ve Avcıkurt, C. (2010). "Şehirlerin turistik bir ürün olarak pazarlaması, örnek şehirler ve Türkiye'deki şehirler üzerine örnekler (Derlemeden oluşmuş bir uygulama)". Adıyaman Üniversitesi Sosyal Bilimler Enstitüsü Dergisi, 3(4): 74-89.

Gemci, D., Gülşen, G. ve Kabasakal F. M. (2009). "Markalar ve markalaşma şartları". Uludă̆ Üniversitesi Mimarlık ve Mühendislik Dergisi, 14(1): 105-114.

Govers, R. (2013): "Why place branding is not about logos and slogans". Place Branding and Public Diplomacy, 9(2): 71-75. https://doi.org/10.1057/pb.2013.11

Görgülü, Y. (2019). "Kentlerin markalaşması sürecinde logoların kimlik inşası: Antalya Örneği Göstergebilimsel bir çözümleme”. Elektronik Cumhuriyet İletişim Dergisi, 1(3): 65-83.

Gross, M. A. (2019). "Color in bank logos - Culture specific or universal? A Color clustering of bank logos in Jordan, China and Germany". EAS Journal of Humanites and Culturel Studies, 1(4): 212-221.

Hildreth, J. (2013): "The joys and sorrows of logos and slogans in place branding". Place Branding and Public Diplomacy, 9(4): 217-222. https://doi.org/10.1057/pb.2013.28

Hospers, G. J. (2010). "Lynch's The Image of the City after 50 Years: City marketing lessons from an urban planning classic". Europen Planning, 18(12): 2073-2081. https://doi.org/10.1080/09654313.2010.525369

Işıklı, S. (2012). Grafik tasarımda logo ve amblemin sektörlere göre renk algısı. Yayınlanmamış yüksek lisans tezi, Haliç Üniversitesi, Sosyal Bilimler Enstitüsü.

Jansson, J. ve Power, D. (2006). The image of the city: Urban branding as constructed capabilities in Nordic city regions. Nordic Innovation Centre.

Kara Düzgün, Ü. (2009). "Giresun adak yerlerinde tespit edilen çeşitli uygulama, inanış ve efsaneler", Uluslararası Sosyal Araştırmalar Dergisi, 2(7): 133-153.

Karadağ, A. ve Turut, H. (2013). "Üniversite öğrencilerinin kentsel çevre algısı üzerine bir araştırma: İzmir örneği”. Coğrafi Bilimler Dergisi, 11(1): 31-51. https://doi.org/10.1501/cogbil_0000000141

Kavaratzis, M. (2007). "City Marketing: The past, the present and some unresolved issues". Geogaphy Compass 1(3): 695-712. https://doi.org/10.1111/j.1749-8198.2007.00034.x

Kavaratzis, M. ve Hatch, J. M. (2013). "The dynamics of place brands: An identity-based approach to place branding theory". Marketing Theory, 13(1): 69-86. https://doi.org/10.1177/1470593112467268

Kavuran, T. ve Çetinkaya, A. (2016). "Elazığ il ve ilçe belediyelerinin logo ve amblemlerinin görsel iletişim tasarımı bağlamında irdelenmesi". Uluslararası Tarihten Günümüze Elazı̆̆ Uluslararas1 Kongresi Bildiriler (17 Kasım 2015) Kitab1 Cilt:2 içinde: 1147-1163.

Kaypak, Ş. (2013). "Küreselleşme sürecinde kentlerin markalaşması ve marka kentler”. C. Ü. İktisadi ve İdari Bilimler Dergisi, 14(1): 335-355. 
Keskin Karaalan, Ö. S. (1998). Türkiye iller amblemi. Yayınlanmamış yüksek lisans tezi, Marmara Üniversitesi, Sosyal Bilimler Enstitüsü.

Kızılçaoğlu, A. (2014). “Afrika ülkelerinin kâğıt paralarındaki coğrafi unsurlar”. Marmara Coğrafya Dergisi, (29): 1-33. https://doi.org/10.14781/mcd.89821

Kızıltaş, S. (2017). "Mekân pazarlama yaklaşımıyla ülke ve şehir logolarının analizi”. İMÜ Sanat, Tasarım ve Mimarlık Fakültesi Dergisi, 3(2): 214-229.

Köroğlu, A. ve Yağcı, P. (2018). “Türkiye'deki şehirleri imgeleyen logoların doğal ve kültürel miras unsurları açısından çözümlenmesi”. Turizm Akademik Dergisi, 5(1): 63-85.

Kurtoğlu, R. (2017). “ Şehir pazarlaması ve markalaşması kapsamında Yozgat ilinin potansiyelinin değerlendirilmesi ve öneriler". Turkish Journal of Marketing, 2(1): 1-20. https://doi.org/10.30685/tujom.v2i1.18

Lynch, K. (1960). The image of city. The M.I.T. Press.

Martinez, G. J. (2006). "Designing symbols: The Logos of The Spanish autonomous comunities (1977 - 1991)". Journal of Spanish Cultural Studies, 7(1): 51-74. https://doi.org/10.1080/14636200600558695

Nas, E. Ve Topaklı, A. (2017). Kültürel kent imajını etkileyen büyükşehir belediyesi logolarına öznel ve nesnel bir yaklaşım". Sosyal Bilimler Dergisi (SOBİDER), (17): 152-167. https://doi.org/10.16990/sobider.3891

Okay, A. (2000). Kurum Kimliği. Mediacat Yayınları.

Örenç, A. F. (2009). "Geçmişten günümüze Giresun Adası". Uluslararası Giresun ve Doğu Karadeniz Sosyal Bilimler Sempozyumu (09- 11 Ekim 2008) Bildiriler Kitab1, (1): 40-54.

Özcan, M. ve Yazıcıŏglu, E. (2013). “Türkiye'de çay yetiştiriciliğinin sorunları ve öncelikleri”. II. Rize Kalkınma Sempozyumu (3-4 Mayıs 2013) Bildiriler Kitabı içinde 64-77.

Özdemir Ş. ve Karaca Y. (2009). "Kent markası ve marka imajının ölçümü: Afyonkarahisar Kenti imajı üzerine bir araştırma”. Afyon Kocatepe Üniversitesi, İI BF Dergisi, (11): 113-134.

Özer, A. (2003) “Türkiye Cumhuriyeti'nin başkenti Ankara için düşünülen amblem ve tartışmalar”. Anadolu Üniversitesi Sosyal Bilimler Dergisi, 2(1): 95-108.

Özsoy S. A., Tuncay, B. ve Uğur, E. (2017). "Yeni kurulan üniversitelerin amblem ve logolarının grafik tasarım yönünden analizi”. Ulakbilge Dergisi, 5(16): 1643-1661. https://doi.org/10.7816/ulakbilge-05-16-06

Özsöz, M. F. (2018). "Şehir pazarlamasında bir marka şehir olarak Eskişehir'in incelenmesi". USOBED Uluslararası Batı Karadeniz Sosyal ve Beşeri Bilimler Dergisi, 2(1): 12-34.

Papp-Vary ve Farkas, M. (2019). "A Categorization of cauntry logos, or how individual cauntries focus on The heart of the branding programs". Proceedings of IAC in Dressen (25-26 October 2019), 28-50.

P1lıcı, A. (2008). Tarihsel süreçte sembolden ikona: Logo. Yayınlanmamış sanatta yeterlilik tezi, Mimar Sinan Güzel Sanatlar Üniversitesi, Sosyal Bilimler Enstitüsü, İstanbul.

Resmi Gazete (2005). Belediye Kanunu (Tarih:13.07.2005, Sayı:25874).

Sağdıç M. (2014). "Üniversite öğrencilerinin İstanbul'a ilişkin algılarının şehir imajı açısından analizi”. Turkish Studies, 9(2): 1267-1283. https://doi.org/10.7827/turkishstudies.6342 
Saraçoğlu, H. ve Kaya, G. (2010). "Balkan ülkelerinin bayrakları üzerine bir değerlendirme". Karadeniz Dergi, (8): 55-67.

Saraçoğlu, H. (2012). "Türk Cumhuriyetlerinin bayrakları üzerine bir değerlendirme”. Birinci Ulusal Coğrafya Sempozyumu (28-30 Mayıs 2012) Bildiriler Kitabı içinde 487-494.

Şenol, E. ve Saraçoğlu, H. (2013). "Sinop ili doğal ve beşeri çevre özelliklerinin valilik ve belediye amblemlerinde kullanımı”. Sinop İli Değerleri Sempozyumu (15-18 Mayıs 2013) Bildiriler Kitabı içinde, 335-342, Manas Medya.

Tarlakazan, B. E. ve Tıngır, M. (2018). "Selçuklu izleri taşıyan kimi belediye amblemlerindeki sembollerin tarih, kültür ve tasarım açısından incelenmesi". Erzincan Üniversitesi Sosyal Bilimler Enstitüsü Dergisi (ERZSOSDE), 11(1): 111-128.

Tepecik, A. (2002). Grafik sanatlar. Detay Yayıncılık.

Türkan, O. (2018). "Evaluation of spatial symbol on municipal logos: Sample fo Çankırı Province". Current Debates in Gender \& Culturel Studies (Ed: Gülçin Taşkıran ve Ercan Geçkin) içinde, 153-166, IJOPEC Publication.

URL 1. (Erişim: 10.02.2020) https://www.e-icisleri.gov.tr/Anasayfa/MulkiIdariBolumleri.aspx.

Uzun, M. ve Özcan, S. (2014). "Belediye logolarındaki coğrafi sembollerin analizi: Kocaeli örneği”. Uluslararası Sosyal Araştırmalar Dergisi, 7(32): 272-288.

Uzuntaş, H. ve Yazar, T. (2017). "Dijital çağdaki yeni eğilimler bağlamında yapılan amblem / logo tasarım trendleri. Journal of Interdisciplinary and Intercultural Art, 2(2): 99-112. https://doi.org/10.29228/ijiia.2.17.

Vermeer, R. A. (2011). "Squares, water and historic buildings: The transforming power of city marketing on urban symbolism in Ghent, Belgium". Cities Full of Symbols: ATheory of Urban Space and Culture (Ed: Peter J. M. Nas) içinde, 55-84, Leiden University Press.

Vural, B. B. (2010). Şehir markası yaratma süreci ve Edirne şehir markası için bir model önerisi. Yayınlanmamış yüksek lisans tezi, Trakya Üniversitesi, Sosyal Bilimler Enstitüsü.

Yenipınar, U. ve Yıldırım, O. (2016). "Destinasyon markalaşmasında yerel simgelerin logo ve amblemlerde kullanılması: Muğla araştırması". Seyahat ve Otel İşletmeciliği Dergisi, 13(1): 28-46.

Yerkan, M. (2010). Türkiye'deki üniversitelerin amblemleri. Yayınlanmamış yüksek lisans tezi, Marmara Üniversitesi, Türkiyat Araştırmaları Enstitüsü.

Yıldırım, M. (2018). "Samsun'un belediye logolarında kullanılan coğrafi sembollerin analizi”, Uluslararas1 Sosyal Araştırmalar Dergisi, 11(61): 375-389. https://doi.org/10.17719/jisr.2018.2928

Yılmaz, İ. (2015). İstanbul Büyükşehir Belediyesi’nin kurumsal kimliğinin grafik tasarım açısından analizi. Yayınlanmamış yüksek lisans tezi, İstanbul Arel Üniversitesi, Sosyal Bilimler Enstitüsü.

Yiğit, A., Çakır, S., Yıldız, G. ve Aslım, G. (2011). "Bayraklarda kullanılan hayvan figürleri üzerine bir inceleme". Veteriner Hekimler Derneği Dergisi, 82 (2): 51-58.

Yüksel, A. (2017). "Rus işgal yılları ve Harşit Müdafaası şehitleri”. Harşit Vadisi Tarih, Coğrafya, Kültür (Ed: M. Fatsa ve M. Özmenli) içinde: 168-182, ASD Grafik

Zaman, M. (2004). “Türkiye'de findık bahçelerinin coğrafi dağılışı ve üretimi”. Doğu Coğrafya Dergisi, 9(11): 233-252. 
Zeren, H. E. (2011). "Stratejik kent yönetimi ve kent markası oluşturma süreci”. Kahramanmaraş Sütçü İmam Üniversitesi İktisadi ve İdari Bilimler Fakültesi Dergisi, 1(2): 175-200.

Zeybek, B. ve Ünlü, D. G. (2016). “A view on countries' tourism logos, slogans, contents and figural characteristics within the concept of country identity". Informacijos Mokslai /Information Sciences (76): 26-41. 